\title{
Keresletvezérelt lakáspiaci modell a lakáshitelezést szabályozó makro- prudenciális eszközök tanulmányozására
}

\begin{abstract}
A makroprudenciális politika egyik feladata a lakáshitelezés folyamán fellépő rendszerszintü kockázatok csökkentése. A nemteljesítés valószínüségét és az ebből fakadó hitelezési veszteségeket minden hitelnél egyedi jellemzők befolyásolják, ezért a makroprudenciális eszközök bankrendszeri stabilitásra gyakorolt hatásának vizsgálatához olyan ágensalapú lakáspiaci modellt fejlesztettünk, amely lehetőséget ad a háztartások kellő mértékű heterogenitásának szerepeltetésére. A modellt egymillió háztartással futtattuk, amelyek jellemzőit magyar adatbázisok felhasználásával generáltuk. A lakáspiac keresletvezérelt, a háztartások döntését preferenciájuk, jövedelmük és a makroprudenciális szabályokból fakadó hitelezési korlátok határozzák meg. Megvizsgáljuk, hogy a jövedelemarányos törlesztőrészletre és a hitelfedezeti mutatóra vonatkozó korlátok különböző kombinációi mellett hogyan alakul a bankrendszer jövedelmezősége, stabilitása, valamint a háztartások jóléte. Az egyes kombinációk megítélése függ a sokkokra vonatkozó feltételezésektől és a döntéshozó preferenciájától, mivel a bankok jövedelmezőségét és a háztartások jólétét eltérően befolyásolják az adósságfékszabályok. A modell eredményei alapján a bankrendszer hosszú távú jövedelmezősége szempontjából nem célszerü a jelenlegi 80 százalékos hitelfedezeti korlátnál szigorúbb előírást alkalmazni.* Journal of Economic Literature (JEL) kód: C63, G21, G28, R21.
\end{abstract}

\section{Bevezetés}

A gazdaság fenntartható növekedéséhez stabilan működő bankrendszerre van szükség, amely a gazdaságot vagy közvetlenül a pénzügyi rendszert érő sokkok esetén is képes megbízhatóan folytatni a hitelezési tevékenységet. A makroprudenciális politika célja olyan szabályozói előírások meghatározása, amelyek rendszerszinten mérsékelni tudják a kockázatok felépülését, valamint a sokkokkal szemben

* A szerzők köszönettel tartoznak Hosszú Zsuzsannának a modell fejlesztése során nyújtott segítségéért.

Mérő Bence, Magyar Nemzeti Bank, Budapesti Corvinus Egyetem (e-mail: merob@mnb.hu).

Vágó Nikolett, Magyar Nemzeti Bank (e-mail: vagon@mnb.hu).

A kézirat első változata 2018. június 22-én érkezett szerkesztőségünkbe.

DOI: http://dx.doi.org/10.18414/KSZ.2018.11.1115 
ellenállóbbá teszik a bankrendszert a kockázatok materializálódása esetén. Mivel a hitelezési tevékenység jelentős része a háztartási szegmenshez, azon belül is a lakáscélú jelzáloghitelekhez (továbbiakban lakáshitelekhez) kapcsolódik, olyan modelleket kell kifejleszteni, amelyek segíthetnek a lakáspiac müködésének megértésében: különös tekintettel a lakáshitelezési gyakorlat és az ingatlanpiac helyzetének kölcsönhatására, valamint az ingatlanpiaci ciklusoknak a fennálló lakáshitelek kockázatosságára gyakorolt hatására.

Magyarországon a lakáshitelezést jelenleg közvetlenül két makroprudenciális szabály korlátozza, ezek az úgynevezett adósságfékszabályok. Az adósságfékszabályok a háztartások túlzott mértékủ eladósodását korlátozzák, hogy rendszerszintű sokkok esetén ne érje túl nagy veszteség a bankrendszert a túlzottan eladósodott háztartások tömeges nemteljesítővé válásával. Az egyik adósságfékszabály a jövedelemarányos törlesztörészlet (payment-to-income, PTI) mértékét szabályozza, a másik pedig a hitelfedezeti mutató (loan-to-value, LTV) nagyságára ír elő maximális értéket. A PTI maximális értéke 50 százalék lehet, vagyis egy bank csak olyan mértékű lakáshitelt folyósíthat egy háztartásnak, amelynek a havi törlesztőrészlete nem haladja meg a háztartás igazolt havi nettó jövedelmének 50 százalékát. ${ }^{1}$ Az LTV maximális értéke 80 százalék lehet, vagyis a lakáshitel mértéke nem lehet nagyobb, mint az abból megvásárolt ingatlan értékének 80 százaléka, ily módon legalább 20 százalék önerőre van szükség a lakáshitel felvételéhez. A PTI-korlát azt a célt szolgálja, hogy minél kisebb valószínűséggel váljon egy háztartás nemteljesítővé, az LTV-korlát pedig elsősorban azt, hogy csőd esetén minél kisebb veszteség érje a bankot.

Ennek megfelelően a tanulmányban egy olyan lakáspiaci modellt építünk, amelyben vizsgálni tudjuk a jövedelemarányos törlesztőrészletre és a hitelfedezeti mutatóra vonatkozó előírások hatását a lakáspiacra, valamint a bankrendszer stabilitására. Az adósságfékszabályok pénzügyi stabilitásra vonatkozó aggregált hatását nagyban befolyásolja a hitelt felvevő háztartások heterogenitása. A nemteljesítés valószínűségét és az ebböl fakadó hitelezési veszteségeket minden hitelnél egyedi jellemzők befolyásolják, emiatt félrevezető lehet egyetlen reprezentatív szereplővel modellezni a különböző makroprudenciális eszközök bankrendszerre gyakorolt hatását. Bár a makroprudenciális politikát vizsgáló dinamikus általános egyensúlyi (DSGE) modellek között találunk olyanokat, amelyek lazítják a reprezentatív háztartás feltevését, és többtípusú háztartást szerepeltetnek, azonban az egyensúlyi modell megoldhatósága korlátot szab a megfelelő mértékű heterogenitás bevezetésének. Emiatt a kutatási kérdés vizsgálatára ágensalapú modellt fejlesztettünk, mivel abban megjeleníthető az ágensek tetszőleges mértékủ heterogenitása.

Az ágensalapú modellek az egyensúlyi modellek egyenletrendszereinek megoldása helyett szimulációra épülnek: az egyes szereplők viszonylag egyszerü, de általában az empíria által alátámasztott szabályok szerint döntenek, és ezen döntések

\footnotetext{
${ }^{1} \mathrm{Az}$ elöírás a forinthitelekre vonatkozik, és havi nettó 400 ezer forint alatti háztartási jövedelem esetén érvényes, e fölötti jövedelem esetén 60 százalék a maximális érték. A devizahitelekre a fentieknél szigorúbb korlátok vonatkoznak, míg a legalább ötéves kamatperiódusokban rögzített kamatozású hitelszerződések esetén lazábbak az előírások. Az adósságfék-szabályozás részletei a 32/2014. (IX. 10.) MNB-rendeletben találhatók.
} 
kölcsönhatásaként jelenhetnek meg makroszintü mintázatok a modellben, mint például a lakásárak ciklikus változása. A döntési szabályoknak nem kell az egyensúlyhoz kötődniük, emiatt a heterogenitásból fakadó előnyökön túl az ágensalapú modellekben a DSGE-modellekben megszokottaknál realisztikusabb feltevésekkel is élhetünk a szereplök viselkedéséröl.

A tanulmányban bemutatott, heterogén háztartásokból álló, ágensalapú lakáspiaci modellben a lakásvásárlás és az ehhez kapcsolódó hitelezés fő jellemzőire koncentrálunk. Emiatt a kínálati oldal súrlódásaitól eltekintünk, és keresletvezérelt lakáspiacot szerepeltetünk. A modell a lakáspiacra helyezi a hangsúlyt, makrogazdasági részt nem tartalmaz, ennek megfelelően a jövedelmek és a foglalkoztatás alakulása exogén. A szimulációk során azt elemezzük, hogy a jövedelmeket és a foglalkoztatást érő sokkok miként hatnak a lakáshitelezésre és a lakáspiacra. Vizsgálódásunk középpontja a különböző adósságfékszabályok hatása a bankrendszer jövedelmezőségére, stabilitására, valamint a háztartások jólétére, amikor a gazdaságot különböző sokkok érhetik. A modellben egymillió háztartást szerepeltettünk, amelyek jellemzőit magyar adatok felhasználásával generáltuk.

Tudomásunk szerint a tanulmányban ismertetett modell az első olyan lakáshitelezést vizsgáló ágensalapú modell, amelyben különböző adósságfék-kombinációk hatását elemzik. ${ }^{2} \mathrm{Az}$ ágensalapú irodalomban néhány példát találunk arra, hogy az ágenseket mikroszintű adatok felhasználásával generálják, mint például Axtell és szerzőtársainak [2014] Washington, D. C. lakáspiacára vagy Baptista és szerzötársainak [2016] az Egyesült Királyság lakáspiacára felírt modelljében. Modellünkben öt magyar adatbázis felhasználásával generáltuk a háztartásokat, nem csupán eloszlások alapján, hanem a legtöbb jellemzőt tekintve konkrét megfigyelések segítségével, így csak kevés jellemző esetében kellett feltevéssel élnünk a mögöttes adatgeneráló folyamatról.

A tanulmány a következőképpen épül fel. Elöször betekintést nyújtunk a releváns szakirodalomba, majd ismertetjük modellünket, és részletesen tárgyaljuk, hogy milyen adatbázisok és módszerek segítségével próbáltuk a modellt a magyar adatokhoz igazítani. A különböző makrogazdasági sokkforgatókönyvek hatásának elemzése után különböző adósságfékkorlátok mellett vizsgálunk sokkhatásokat, hogy támpontot kapjunk a makroprudenciális szabályozást illetően. Majd robusztusságvizsgálatokat végzünk, végül a tanulmányt összegzéssel zárjuk.

\section{Szakirodalmi áttekintés}

A lakáspiacot és a lakáshitelezést kezdetben jellemzően dinamikus általános egyensúlyi modellkeretben vizsgálták. Kiyotaki-Moore [1997] a gazdasági ciklusok, az endogén - fedezet értékétől függő - hitelfelvételi korlátok és az ingatlanárak kapcsolatát vizsgálta, kizárólag vállalati hitelfelvétel mellett. A hitelkorlátok és az ingatlanárak

\footnotetext{
${ }^{2}$ Az irodalomban jellemzőbb az LTV-korlátok vizsgálata, mint például Axtell és szerzőtársai [2014], valamint Erlingsson és szerzőtársai [2014] modelljében.
} 
közötti kölcsönhatás a sokkok hatásának fennmaradásához, felerősödéséhez és továbbterjedéséhez vezetett. Iacoviello [2005] olyan modellt épített, melyben a vállalatok mellett a háztartások is felvehetnek hitelt ingatlanfedezet mellett. KiyotakiMoore [1997] modelljéhez hasonlóan a felvehető hitel nagysága függ a fedezet értékétől, vagyis közvetetten az ingatlanárak alakulásától; a háztartások hiteltörlesztési terhei pedig nominálisan jelentkeznek. Az eredmények alapján a háztartási hitelezés beépítése, illetve a nominális adósság szerepeltetése hatással van a sokkok lefutására, valamint a monetáris politika hatásmechanizmusára.

Kiyotaki és szerzőtársai [2011] a lakásárak, az aggregált termelés és a háztartások viselkedése közötti kapcsolatot vizsgálja egy olyan modellben, amelyben föld és töke segítségével építenek ingatlanokat. Kalibrált modelljük eredménye szerint az ingatlanárak nagyobb mértékben reagálnak az exogén kamatlábak vagy a várható termelékenység változására, ha az adott gazdaság ingatlanáraiban relatíve nagy súllyal jelenik meg a földterület nagysága, ami jelentős mértékủ újraelosztáshoz vezet a nettó lakásvásárlók és eladók között. A hitelezési korlátok változtatásának azonban alig van hatása a lakásárakra. Kuang [2014] modellje, amelyben a racionális várakozások feltevéssel szemben a háztartások nem ismerik egymás preferenciáit és várakozását, képes megjeleníteni lakáspiaci és hitelciklusokat. A modellben endogén módon kialakuló lakásárciklus, illetve a háztartások adósságállományának és aggregált fogyasztásának alakulása összhangban van az Egyesült Államokban 2001 és 2008 között megvalósuló folyamatokkal. A modellben a nagyobb tőkeáttétel az ár- és mennyiségi ingadozások felerősödéséhez és ezáltal jelentős gazdasági volatilitáshoz vezet, ami egy újabb érv lehet a bankok tőkeszabályozása mellett.

A lakáspiacot tartalmazó dinamikus sztochasztikus általános egyensúlyi (DSGE) modellek egy része a makroprudenciális politika szerepének, valamint a monetáris és makroprudenciális politika kapcsolatának vizsgálatára helyezi a súlyt. Kannanés szerzőtársai [2012] a modellszimulációk alapján arra a következtetésre jutott, hogy az optimális monetáris és makroprudenciális politika meghatározásához elengedhetetlen pontosan felmérni, hogy milyen sokk áll a pénzügyi kondíciók és eszközárak változásának hátterében. Rubio-Carrasco-Gallego [2014] modelljében a hitelezési folyamatokra reagáló hitelfedezeti szabályozás jelenik meg makroprudenciális politikai eszközként, míg a monetáris politika működését az inflációtól és a kibocsátástól függő Taylor-szabály határozza meg. Eredményeik alapján optimumban mind a monetáris, mind a makroprudenciális hatóság saját céljára összpontosítva hozza meg döntését, mivel így hatékonyabban tudják elősegíteni a makrogazdasági és a pénzügyi stabilitást. A szerzők továbbá felhívják a figyelmet arra, hogy az össztársadalmi szinten érdemi jóléti nyereséggel járó makroprudenciális szabályozás eltérően érinti a hitelfelvevő és a megtakarító háztartásokat: a pénzügyi stabilitás erősítése révén a hitelfelvevők jólétére jelentős pozitív hatással van, miközben a megtakarítókat kissé kedvezőtlenül érinti.

Rubio-Comunale [2016] a makroprudenciális politika szerepét egy két gazdaságból álló DSGE-modellben vizsgálta, ahol az egyik fél az euróövezetet reprezentálja, a másik pedig a litván gazdaságot mintázza. A makroprudenciális eszköz a modellben a hitelrésre reagáló hitelfedezeti korlát, amelyre optimumban az 
euróövezet hitelfedezeti szabályozásától eltérő előírás vonatkozik. Ortalo-MagnéRady [2006] olyan egyensúlyi életciklusmodellt fejlesztett, amelyben a háztartások heterogének, és hitelkorlátok kötik őket. Ez hatással van a megtakarításukra, bizonyos esetekben a lakásvásárlás idejére, valamint a vásárolt lakás méretére is. A modellben a jövedelmek változása a lakásárakban nagymértékủ ingadozást okozhat. A háztartások heterogenitásának bevezetése valóban fontos a lakáspiac vizsgálatakor. A legkönnyebben az ágensalapú modellekben lehet megjeleníteni a szereplők nagymértékü heterogenitását.

A szakirodalomban számos olyan ágensalapú modell található, amely alkalmas a lakáspiac vizsgálatára. Gilbert és szerzőtársai [2009] az angol ingatlanpiacot modellezi vevőkkel, eladókkal és ingatlanközvetítőkkel, s modelljükben exogén a háztartások jövedelme. A brit ingatlanpiacra kalibrált modellen végzett szimulációk alapján a hitelfedezeti korlát 100 százalékról 80 százalékra történő mérséklése nemcsak jelentősen alacsonyabb lakásárakhoz vezetne, hanem egyúttal érdemben csökkentené egy - a piac élénkítése érdekében végrehajtott - kamatcsökkentés jelentőségét. Ge [2014] azt mutatja be, hogy miként vezet az ingatlanárak magas volatilitásához bizonyos hitelezési korlátok oldása. Carstensen [2015] a dán lakáspiacot vizsgálja, modelljében a háztartások saját lakásban laknak vagy lakást bérelnek, a költözés valószínüsége pedig korspecifikus. A lakásokat felárral viszik a piacra, az eladatlan lakások felára azonban fokozatosan csökken. A modellben elemezhető a kamatot és a jövedelmet érő sokkok hatása. Axtell és szerzőtársai [2014] Washington, D. C. lakáspiacát modellezi, és az elérhető adatbázisok segítségével generál bizonyos jellemzőket. A felhasznált adatbázisok többek között tartalmazzák az 1997-2009 közötti összes ingatlanpiaci tranzakciót. Ágensalapú modelljük több mint kétmillió háztartást tartalmaz, és endogén módon jönnek létre benne ingatlanár-buborékok. Következtetésük szerint a szigorúbb kamatpolitika csak kismértékben csökkenti a buborék nagyságát, a tőkeáttétel szigorításának viszont jelentős hatása lehet.

Axtell és szerzőtársai [2014] modelljét alapul véve, Baptista és szerzőtársai [2016] az angol ingatlanpiacra fejlesztett ágensalapú modellt. A lakások egyetlen tulajdonságban különböznek egymástól, amit minőségnek vagy méretnek is lehet tekinteni, a háztartások pedig mindig a rezervációs árukból a piacon elérhető legjobb minőségü lakást vásárolják meg. A modellben a lakások piacra vitele függ a piac telítettségétől, a ciklusok pedig a befektetési céllal vásárlók döntéseinek következtében alakulnak ki. A szerzők megvizsgálták a Bank of England által 2014 óta alkalmazott makroprudenciális eszköz, a jövedelemarányos hitelre vonatkozó (loan-to-income, LTI) korlát hatását, és azt találták, hogy e korlát alkalmazása mérsékelni tudja a lakáspiaci ciklusokat.

A lakáspiacot makrogazdaságba ágyazottan vizsgálja Erlingsson és szerzőtársai [2014], valamint Ozel és szerzötársai [2016]. Mindkét modell a jelenleg egyik legösszetettebnek tekinthetö ágensalapú makromodellt, a EURACE-t veszi alapul (lásd Deissenberg és szerzőtársai [2008]). A modellben a lakáshitelezéshez köthető endogén pénzteremtés segít az aggregált kereslet stabilizálásában. A jelzálog-hitelezés feltételeinek lazítása esetén azonban a többletpénz már kevésbé javít a makrogazdaság teljesítményén, miközben pénzügyi stabilitási kockázatok alakulhatnak ki. 


\section{A modell bemutatása}

A modell szereplői a heterogén háztartások, akik a lakáspiacon vásárlóként, eladóként vagy bérlőként jelennek meg, valamint a kereskedelmi bank, mely bizonyos feltételek mellett lakáshitelt nyújt a háztartások számára.

A háztartások egy adott időszakban vagy lakást bérelnek, vagy saját tulajdonú lakásban laknak. Egy háztartás kezdetben lakást bérel, majd megveszi első lakását, amiből később a családméret változásával párhuzamosan egy nagyobba költözik, végül pedig egy kisebbe. A lakások méretükben különböznek egymástól, az azonos méretü lakások méretkategóriákat alkotnak. A lakások ára méretükkel arányos, így egy méretkategórián belül a lakások ára megegyezik. Minden lakásvásárláskor elsőként a háztartás dönt a maximális vételárról, amelyet lakásvásárlásra kíván fordítani. A maximális vételárat a hitelezési korlátok módosíthatják. A háztartás költözéskor az általa elérhető legnagyobb méretkategóriájú lakást választja.

A modell fejlesztésének célja annak vizsgálata, hogy a különböző makroprudenciális szabályok hogyan hatnak vissza a bankrendszer jövedelmezőségére, stabilitására, valamint a háztartások helyzetére. Mivel nem cél a lakáspiaci tranzakciók részletes modellezése, így költözéskor a háztartás egyből el tudja adni saját tulajdonú lakását. A keresési súrlódások elkerülése érdekében pedig a háztartások nem közvetlenül egymástól veszik meg a lakásokat: az eladó lakást a piac szívja fel, és az adott háztartás egyböl megkapja ingatlana piaci értékét. Vásárláskor a háztartás szintén közvetlenül a piactól vásárol, és a piac minden méretkategóriában mindig képes lakást biztosítani: ha a piac által megvásárolt ingatlanok között nem volna megfelelő méretü, a piac egyből tud újat építeni vagy meglévő lakást átalakítani. A lakáspiac tehát keresletvezérelt a modellben, és súrlódásmentesen mủködik.

A modellben egy kereskedelmi bankot szerepeltetünk, mely a jövedelemarányos törlesztőrészletre és a hitelfedezeti mutatóra vonatkozó (PTI és LTV) korlátok betartása mellett bármekkora összeget képes hitelezni az egyes háztartásoknak. Egyedi szinten tehát lehetnek hitelezési korlátok, bankrendszeri szinten azonban hitelszűke nem befolyásolja a háztartások lakásvásárlását.

\section{A háztartások}

Egy háztartás feltevés szerint 60 évig szerepel a modellben. Egy időszak egy negyedévnek felel meg a modellben, így a háztartások $n_{L}=240$ időszakig szerepelnek benne, amely időtartam az egyének felnőttkori élethosszát jeleníti meg. ${ }^{3}$ A háztartások minden időszakban munkából vagy nyugdíjból származó jövedelmet realizálhatnak $\left(y_{i, t}\right)$, amennyiben nem munkanélküliek. Jövedelmüket fogyasztásra $\left(c_{i, t}\right)$ és lakhatásra fordítják, valamint megtakarítanak belőle (továbbiakban a modellben megtakarításon lakáscélú megtakarítást értünk). Ha egy háztartásnak nincsen saját tulajdonú lakása

\footnotetext{
${ }^{3}$ Az alkalmazott paraméterek értékét a Függelék F2. táblázata tartalmazza, a változók jelölését pedig a Függelék F3. táblázatában összegezzük.
} 
$\left(F_{i, t}=0\right)$, akkor lakást bérel, a lakhatási költség pedig ebben az esetben a bérleti díjat $\left(r_{i, t}^{F}\right)$ jelenti. Ha a háztartás saját tulajdonú lakásban lakik $\left(F_{i, t}=1\right)$, és van a lakáshoz kapcsolódó lakáshitele $\left(L_{i, t}>0\right)$, akkor a lakhatási költség a hitel törlesztőrészlete $\left(l_{i, t}\right)$. Ha nincs hitel a saját tulajdonú lakáson, akkor a háztartásnak nincsen lakhatási költsége. A háztartás a felnőttkora kezdetén $\left(a_{i, t}=1\right)$ valamekkora kezdővagyonnal rendelkezik betét formájában $\left(B_{i}^{0}\right)$, a további időszakokban pedig pénzügyi vagyonának változását a fentiek alapján az (1) költségvetési korlát írja le:

$B_{i, t+1}-B_{i, t}=y_{i, t}-c_{i, t}-r_{i, t}^{F}-l_{i, t}-c_{i, t}^{F}$,

ahol $c_{i, t}^{F}$ a lakásvásárláshoz és -eladáshoz kapcsolódó pénzmozgásokat jelöli.

A háztartásokat megkülönböztetjük végzettség szerint, három kategóriába osztva: képzetlen háztartások (legfeljebb alapfokú végzettséggel rendelkezők), közepesen képzett háztartások (középfokú végzettséggel rendelkezők) és magasan képzett háztartások (felsőfokú végzettséggel rendelkezők).

A háztartás lehet egyfős $\left(n_{i}^{H}=1\right)$ és kétfős $\left(n_{i}^{H}=2\right)$. Kétfős háztartás esetén a háztartás tagjai külön-külön kapnak munkajövedelmet, és a háztartás tagjai egymástól függetlenül válhatnak munkanélkülivé. Ennek a megkülönböztetésnek éppen ezért a hitelezési kockázatoknál lesz szerepe: kétfős háztartás esetén van adóstárs, és emiatt a hitel kisebb valószínűséggel fog nemteljesítővé válni.

A foglalkoztatási helyzetet leszámítva, a kétfős háztartások tagjai feltevés szerint mindenben megegyeznek egymással: képzettségüket tekintve ugyanabba a kategóriába tartoznak, amennyiben dolgoznak, munkabérük ugyanakkora, közösen fogyasztanak és halmoznak fel, valamint életkoruk is megegyezik. A továbbiakban ezért mindig a háztartás képzettségére, bérére, betétállományára és életkorára fogunk hivatkozni. Kétfős háztartás esetén egy-egy fö bére a háztartás bérének a fele.

Egy háztartás 240 időszaka a felnőttkori élethosszt jeleníti meg, amikor az egyének már jövedelemmel rendelkeznek: munkajövedelemmel $\left(w_{i, t}\right)$ vagy nyugdíjjal $\left(y_{i, t}^{P}\right)$. Az első időszakban a háztartások kapnak valamekkora kezdővagyont és kezdőbért $\left(w_{i}^{0}\right)$. Az életkor elörehaladtával nő a háztartások potenciális bére $\left(w_{i}^{P}\right){ }^{4}$ Mindhárom képzettségi típusnak megvan a rá jellemző bérnövekedési pályája, valamint a képzettségére jellemző munkanélkülivé válás valószínűsége, továbbá munkanélkülivé válás esetén a munkanélküliség hossza. A nyugdíjaskor elérésével $\left(n_{P}=180\right.$. időszaktól kezdve) a háztartások bér helyett nyugdíjat kapnak. Mindhárom képzettségi kategóriában ugyanakkora arányban $\left(r^{P}\right)$ csökken a rendszeres jövedelem mértéke nyugdíjba vonuláskor, és ez teljesen kiszámítható, mert a nyugdíjas háztartások nem válhatnak munkanélkülivé.

A háztartások eleinte lakást bérelnek (potenciális bérük $\beta$ részéért, vagyis $r_{i, t}^{F}=\beta w_{i, t}^{P}$ ), majd később lakást vesznek lakhatási céllal. A modellben nincsenek befektetési céllal vásárló háztartások, és egy háztartásnak egyszerre legfeljebb egy saját tulajdonú ingatlana lehet (amelyben éppen lakik). A háztartások a felnőttkor kezdetén rendelkezhetnek

\footnotetext{
${ }^{4}$ A potenciális bér az a munkajövedelem, amelyet a háztartás akkor realizál, ha az adott időszakban foglalkoztatott. Ha egy kétfős háztartásnak csak az egyik tagja foglalkoztatott, akkor a háztartás munkajövedelme a potenciális bér fele.
} 
induló vagyonnal betétek formájában, azonban kezdetben nincsen saját lakásuk (ezért bérelnek). A bérléssel párhuzamosan jövedelmük egy részét megtakarítják. Az így felhalmozott betétállományuk szolgál önerőként az első lakás vásárlásakor.

Ha a háztartás mindkét tagja foglalkoztatott, fogyasztási-megtakarítási döntése függ egyrészt attól, hogy rendelkezik-e saját tulajdonú lakással, illetve fennálló lakáshitel esetén még a jövedelemarányos törlesztőrészlet nagyságától is. Abban az esetben, ha egy háztartásnak nincs saját tulajdonú lakása $\left(F_{i, t}=0\right)$, akkor a fogyasztása és megtakarítása a (2) és a (3) egyenlettel írható le: ${ }^{5}$

$c_{i, t}=\left(1-s_{i, t}\right) y_{i, t}$

$s_{i, t}=s_{0}^{R}+\xi \frac{y_{i, t}}{100000 \times n_{i}^{H}}$,

vagyis a bérleti időszak alatt a háztartások megtakarítási rátája a háztartás egy főre jutó jövedelmétöl függ oly módon, hogy a megtakarítási ráta minimuma $s_{0}^{R}$, amely érték százezer forintonként $\xi$-vel nő.

Lakástulajdonosként a háztartások eltérő szabály alapján takarítanak meg és fogyasztanak:

$$
\begin{array}{ll}
c_{i, t}=\left(1-s^{R}\right) y_{i, t}, & \text { ha } \quad \frac{l_{i, t}}{y_{i, t}}<s^{R}, \\
c_{i, t}=y_{i, t}-l_{i, t}, & \text { ha } \quad \frac{l_{i, t}}{y_{i, t}} \geq s^{R},
\end{array}
$$

vagyis a háztartások egységesen a jövedelmük $s^{R}$ részét takarítják meg, viszont ebből fedezik a lakáshitel törlesztőrészletét is. Ha a jövedelemarányos törlesztőrészlet nagyobb a megtakarítási rátánál, akkor az (5) képletnek megfelelően a háztartás törlesztőrészleten felüli jövedelmét fogyasztásra fordítja. Mivel a törlesztőrészlet egy része a háztartás tőketartozását csökkenti, a háztartás szemszögéből nézve megtakarításnak tekinthetö, emiatt a tényleges megtakarítási ráta továbbra is háztartásonként eltérő marad.

Az első lakásvásárlást követően modellünkben a háztartások alapvető motivációja a költözésre a családméret változása: ennek következtében azzal a feltételezéssel éltünk, hogy a háztartások fiatalon viszonylag kisebb méretű lakást vásárolnak, majd a gyermekszám növekedésével párhuzamosan nagyobb lakásba költöznek, végül nyugdíjasként kisebbe. Amiatt, hogy nyugdíjasként kisebb méretü lakásba költöznek, hitelfelvételre ekkor már jellemzően nincsen szükség. Az első lakás vásárlásának ideje háztartásonként eltérő lehet, a második lakásvásárlást egységesen 10 évvel (40 időszakkal) később próbálják megejteni, a harmadik lakásvásárlásra pedig a nyugdíjkorhatár elérésekor kerül sor.

Amikor egy háztartás lakást vásárol, a rezervációs árát $\left(p_{i, t}^{R}\right)$ a preferenciái határozzák meg a következő módon:

\footnotetext{
${ }^{5}$ Ha a háztartás legalább egyik tagja munkanélküli, a fogyasztást a (7) egyenlet írja le.
} 
$p_{i, t}^{R}=\left\{\begin{array}{c}\theta_{i, t} w_{i}^{0}, \text { első lakásvásárlás esetén } \\ \varsigma_{1} \theta_{i, t} w_{i}^{0}, \text { második lakásvásárlás esetén } \\ \varsigma_{2} \varsigma_{1} \theta_{i, t} w_{i}^{0}, \text { harmadik lakásvásárlás esetén }\end{array}\right.$

Minden háztartásnak van egy rá jellemző kiinduló lakásárarány-paramétere $\left(\theta_{i, t}\right)$, ami azt mutatja meg, hogy kiinduló jövedelmének hányszorosát szeretné az első lakására fordítani. Az egyedi lakásárarány-paraméter a második lakásvásárlásnál minden háztartás esetében a $\varsigma_{1}=1,5$-szeresére nő, a harmadik vásárlásnál pedig egységesen a megnövelt érték $\varsigma_{1}=0,8$-szorosára csökken. A preferenciabeli különbségek tehát végig megmaradnak, de az egységes, hogy a háztartások második vásárlásuknál nagyobb lakásba költöznek, harmadik vásárlásuknál pedig kisebbe (de az elsőnél nagyobba), és a méretváltozás aránya is egységes.

Ha egy háztartás betétállománya kisebb a rezervációs áránál, a különbözet elöteremtéséhez hitelért folyamodik a bankhoz. A felvehető hitelösszeget két korlát befolyásolja: a törlesztőrészlet nem haladhatja meg a háztartás jövedelmének egy bizonyos százalékát (PTI-korlát), a felvehető hitelösszeg pedig nem haladhatja meg az ingatlan értékének egy bizonyos hányadát (LTV-korlát), vagyis a háztartásnak kellő önerővel kell rendelkeznie. A hitelezési korlátokat figyelembe véve alakul ki a maximális vételár, amelyet a háztartás ki szeretne és ki is tud fizetni a lakásért, és ez alapján az általa elérhető legnagyobb méretkategóriájú lakást választja. Az egymást követő méretkategóriák között 5 százalékos különbség van a lakás alapterületében.

Azok a háztartások, melyek a költözés tervezett időszakában rendelkeznek már saját lakással, elsőként értékesítik meglévő lakásukat a piacon (nem közvetlenül egy másik háztartásnak adják el), s megkapják érte a lakás piaci értékét, amivel növekszik a betétállományuk. Így közvetlenül a lakásvásárlás előtt egy háztartás összes vagyona betétben van, ami teljes egészében beszámítható önerőnek. Ennek az egyszerűsítésnek köszönhetően a lakás eladásakor nem merülnek fel tranzakciós nehézségek, így az áthidaló hiteleket sem kell modellezni.

Amennyiben a háztartás legalább egy tagja munkanélküli a lakásvásárlás tervezett időpontjában, a lakásvásárlást elhalasztják egészen addig, amíg a háztartás összes tagja ismét foglalkoztatott lesz. Ennek oka egyrészt, hogy munkanélküli-háztartásoknak a bank nem hitelez, másrészt a háztartás sem bocsátkozik nagy költekezésbe.

Amikor a háztartás legalább egyik tagja munkanélkülivé válik, fogyasztása a következőképpen alakul:

$c_{i, t}=c_{i, t}^{U}=\max \left[y_{i, t}-l_{i, t}, \min \left[B_{i, t}+y_{i, t}, \delta w_{i, t}^{P}\right]\right]$,

vagyis a háztartás nem takarít meg, és a hiteltörlesztésen felüli jövedelmét igyekszik elfogyasztani. A háztartásoknak van minimális fogyasztásuk $\left(\delta w_{i, t}^{P}\right)$ is, ami a potenciális bérüknek egy meghatározott része. Ezt a fogyasztást akkor engedheti meg magának a háztartás, ha az adott időszaki jövedelméből és a korábbi időszakok pénzügyi megtakarításaiból fedezni tudja. A napi szükségletek miatt a minimális fogyasztást előnyben részesíti a hiteltörlesztéshez képest. Ha a háztartásnak 
volt hitele, a törlesztőrészletet csak a minimális fogyasztást követően fizeti meg a banknak. Ha ennek a kötelezettségének mégsem tudna teljes mértékben eleget tenni, akkor nemteljesítővé válik.

A nemteljesítővé válás elsődleges forrása a munkanélküliség. Recesszió esetén ez kiegészül az erkölcsi kockázattal: a háztartások egy része úgy dönt, hogy nem törleszt, bár képes lenne rá. ${ }^{6}$ Minél magasabb az aktuális jövedelemarányos törlesztőrészlet vagy a fennálló tartozásnak az ingatlanfedezet piaci értékéhez viszonyított aránya, annál nagyobb az erkölcsi kockázatból eredő nemteljesítés valószínűsége. Ez a kapcsolat a (8) képlettel írható le:

$\pi_{i, t}^{m}=\eta\left(P T I_{i, t}-P T I^{m}\right) L T V_{i, t}$, ha $P T I_{i, t}>P T I^{m}$,

ahol $\pi_{i, t}^{m}$ a $t$-edik (recessziós) időszakban az $i$-edik háztartás erkölcsi kockázatból fakadó nemteljesítővé válásának valószínűsége, $P T I_{i, t}$ az $i$-edik háztartás aktuális jövedelemarányos törlesztőrészlete, $P T I^{m}$ az erkölcsi kockázathoz szükséges minimális törlesztési kötelezettség a jövedelem arányában, $L T V_{i, t}$ az $i$-edik háztartás aktuális fedezetarányos hitelállománya, $\eta$ pedig skálázási együttható. A modellben az erkölcsi kockázatot azért korlátoztuk a recesszió időszakára, mert a nemteljesítés társadalmi szintű problémává eszkalálódásával sok háztartás arra számíthat, hogy az állam aktívan beavatkozik az eladósodott háztartások megsegítése érdekében.

Miután egy háztartás elérte a maximális életkort, a helyére egy vele azonos jellemzőkkel rendelkező fiatal, felnőttkorának első időszakában járó háztartás kerül.

\section{A bankrendszer és a lakáspiac}

A bankrendszert a modellben egy kereskedelmi bank képviseli, a lakáspiacon pedig egy közvetítő tevékenykedik, amely biztosítja a lakáspiac súrlódásmentes müködését.

A bankrendszer müködésére hatással van a makroprudenciális hatóság, amely maximális PTI- és LTV-korlátokat határoz meg. A bank korlátlanul hitelezhet a háztartásoknak a PTI- és LTV-korlátok betartása mellett. A bank által alkalmazott PTIés LTV-korlát lehet alacsonyabb a makroprudenciális hatóság által előírt maximumértékeknél, föként amikor bizonyos időszakokban eltérö kockázatvállalási hajlandóság jellemzi a bankot. Az egyes háztartásoknak pedig kockázatosságuknak megfelelően különböző kamatok $\left(i_{i, t}\right)$ mellett ad hitelt a bank. A lakáshitel annuitásos, fix kamatozású, futamideje pedig egységesen 25 év (100 időszak a modellben). ${ }^{7}$

Amennyiben valamelyik háztartás munkanélküliség miatt nemteljesítővé válik egy adott időszakban $\left(B_{i, t}+y_{i, t}-c_{i, t}^{U}<l_{i, t}\right)$, a bank felszámolási eljárás keretében értékesíti az ingatlant piaci értékének $\gamma$ részéért. A modellünkben nem különítettük el területileg

\footnotetext{
${ }^{6}$ Dancsik és szerzőtársai [2015] mikroszintű adatbázisokon végzett elemzésben bemutatta, hogy a magyar bankrendszerben 2015. január 31-én fennálló nemteljesítő jelzáloghitel-állománynak egy érdemi - becslésük szerint 10-20 százalékos - része erkölcsi kockázatból eredően vált nemteljesítővé.

${ }^{7}$ A szimulációkban alkalmazott magas futamidővel nem kell a háztartások futamidőre vonatkozó döntését modelleznünk, mert ekkora futamidő esetén már csak minimális alkalmazkodási lehetősége lenne a hitelkorlátos háztartásoknak.
} 
és minőségileg a lakásokat, ezek azonban a valóságban mind hatással vannak egy ingatlan forgalomképességére. A jelzáloggal terhelt ingatlanok között jelentős lehet azon ingatlanoknak a száma, amelyeket nehéz értékesíteni (fóként lakáspiaci pangás esetén), és ebben az esetben sokkal kisebb áron lehet eladni a fedezetet. Így a $\gamma$ által megragadott értékcsökkenés a makroszinten felmerülő átlagos veszteségeket takarja, beleértve a felszámolási eljárással felmerülő költségeket is. A fedezet érvényesítéséből befolyt összegből a fennálló hiteltartozást megkapja a bank. Ha a befolyt összeg nem elegendő a teljes fennálló adósság visszafizetésére, akkor a különbözetet a bank elkönyveli veszteségként:

$l_{i, t}^{B}=L_{i, t}-\left(B_{i, t}+y_{i, t}-c_{i, t}^{U}+\gamma p_{i, t}^{M}-i_{i, t} L_{i, t}\right)$.

Ha valamelyik háztartás erkölcsi kockázatból adódóan válik nemteljesítővé, akkor a fennálló tartozás $\kappa$ részét könyveli el a bank veszteségként, makroszinten ugyanis a bank behajtások révén hozzá szokott jutni a tartozások egy részéhez.

A lakáspiaci közvetítő minden eladó ingatlant megvesz, és minden méretkategóriában tud lakást eladni. A négyzetméterárak egy adott időszakban egységesek, azonban a kereslet változásának hatására a négyzetméterárak emelkedhetnek vagy csökkenhetnek. Az alap-négyzetméterárra a kereslet függvényében valamekkora felár rakódik:

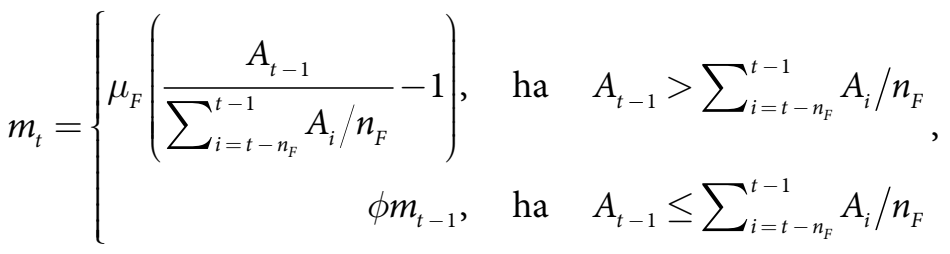

vagyis amennyiben az elmúlt időszakban vásárolt lakások összterülete $\left(A_{t-1}\right)$ nagyobb az elmúlt $n_{F}$ időszak átlagánál, akkor a felár a százalékos eltérés $\mu_{F}$ része, ellenkező esetben a felár az előző időszaki értékének $\phi$ részére csökken.

Az ingatlanárak változására a háztartások is reagálnak, a (11) képlet alapján:

$\theta_{i, t}=\theta_{i}^{0}\left(1+m_{t} \omega\right)$

ahol $\theta_{i}^{0}$ a kiinduló lakásárarány-paraméter időfüggetlen értéke. A háztartások a négyzetméterárak emelkedésével párhuzamosan tehát hajlandók valamivel többet fordítani lakhatásra a jövedelmükből, az árak csökkenése esetén pedig arányaiban kevesebbet hajlandók fizetni, vagyis megváltozik kiinduló lakásárarány-paraméterük. A változás mértéke a piacra jellemző (pozitív vagy negatív) felár értékének $\omega$ része. A háztartások ezzel a viselkedésükkel felerősítik a lakásárciklusokat.

\section{Egy idöszak eseményei}

Egy ágensalapú modellben egy időszak eseményei nem szimultán történnek, hanem jól meghatározott sorrendben. A modellben egy időszakban (egy negyedévben) a következő események követik egymást: 
1. A maximális életkort elérő háztartások helyett újak jönnek létre azonos kiinduló paraméterekkel. A háztartások munkabére emelkedik, de ezt a bért csak az időszak végén kapják meg, amennyiben az adott időszakban foglalkoztatottak voltak.

2. Ha valamelyik háztartás költözési korba lép, ingatlanát eladja a piacon. Amennyiben az ingatlanon volt hitel, a bevételből a fennálló hiteltartozást visszafizeti, a betétállománya pedig a lakás értékének és a hitel különbözetének összegével nő.

3. Kiderül a háztartások tagjainak foglalkoztatottsági státusa: az egyes háztartások tagjai a képzettségükre jellemző valószínűséggel válnak munkanélkülivé.

4. A költözési korba lépő háztartások megpróbálnak lakást venni, de az a háztartás, ahol legalább egy tag munkanélküli, kénytelen elhalasztani az új lakás vásárlását. Azok a háztartások, amelyek korábban elhalasztották a vásárlást, de most már foglalkoztatottak, szintén lakásvásárlóként jelennek meg. Minden egyes háztartás esetében a lakásvásárlás folyamata az alábbi elemekből áll:

a) a háztartás kialakítja a rezervációs árát a rá jellemző lakásárarány-paraméter alapján;

b) ha egy háztartás betétállománya kisebb a rezervációs áránál, a különbözetre hitelajánlatot kér a banktól. A bank korlátozza a felvehető összeget, ha a háztartás önereje nem felel meg a maximális LTV-korlátnak, illetve ha a becsült törlesztörészlet jövedelmének nagyobb arányát tenné ki, mint a bank által alkalmazott PTI-korlát. A becsült törlesztőrészlet meghatározásához a bank előzetesen megbecsüli a leendő hitel kamatát az adott háztartás életkora, jövedelme, mérete (van-e adóstárs), a szerződéses összeg, valamint az önerő alapján. Ha az önerő és a felvehető hitel összege kisebb a rezervációs árnál, a lakásvásárlás maximális vételára csökken;

c) a háztartás a maximális árért elérhető legnagyobb méretkategóriájú ingatlant vásárolja meg;

d) a háztartás szükség esetén megfelelő mértékü hitelt vesz fel a banktól.

5. A háztartások megkapják a bérüket. A saját lakással nem rendelkező háztartások bérleti díjat fizetnek. Minden háztartás fogyaszt. Ezt követöen kerül sor a hiteltörlesztésekre:

a) recesszió esetén a háztartások egy része erkölcsi kockázat alapján nemteljesítővé válik. A többi foglalkoztatott törleszt;

b) azon munkanélküliséggel sújtott háztartások, amelyeknek van elég betétállománya, törlesztenek, a többi nemteljesítővé válik;

c) a munkanélküliség miatt nemteljesítővé váló háztartások esetében felszámolási eljárás keretében értékesítik az ingatlanfedezetet. A háztartás betétállománya az ingatlanfedezet érvényesítésével szerzett összeggel (az ingatlan aktuális piaci értékének $\gamma$ része) nő, a bank pedig ebből megpróbálja behajtani a fennálló tartozást;

d) az erkölcsi kockázat következtében nem teljesítő háztartások esetében a bank megkapja a fennálló tartozás $(1-\kappa)$-ad részét.

\section{Adatok}

A modellben szereplő háztartások jellemzőit és a foglalkoztatással kapcsolatos paramétereket a Magyar Nemzeti Bank L11 kódú adatszolgáltatása, a Központi Hitelinformációs Rendszer (KHR), az szja-adatbázis, a Bértarifa-felmérés, valamint a 
Munkaerö-felmérés (MEF) adatai alapján számszerüsítettük, a továbbiakban ismertetett módon. A felhasznált adatbázisok föbb jellemzői az 1. táblázatban láthatók, részletesebb leírásuk pedig megtalálható a Függelékben.

1. táblázat

A felhasznált adatbázisok főbb jellemzői

\begin{tabular}{|c|c|c|c|}
\hline & \multicolumn{3}{|c|}{ Összekötött adatbázisok } \\
\hline & $\mathrm{L} 11$ & KHR & SZJA \\
\hline Adatgazda & MNB & BISZ Zrt. & NAV \\
\hline Mikroegység & hitelszerződés & hitelszerződés & adóköteles egyén \\
\hline Főbb változók & $\begin{array}{l}\text { ügyféladatok, szerződés } \\
\text { jellemzői, fedezetérték }\end{array}$ & adóstárs, futamidő & jövedelmek, adóterhek \\
\hline \multirow[t]{3}{*}{ Felhasználás } & $\begin{array}{l}\text { háztartások generálása, } \\
\text { kamatregresszió }\end{array}$ & $\begin{array}{l}\text { háztartások generálása, } \\
\text { kamatregresszió }\end{array}$ & háztartások generálása \\
\hline & \multicolumn{3}{|c|}{ Különálló adatbázisok } \\
\hline & Bértarifa & MEF & \\
\hline Adatgazda & NFSZ & $\mathrm{KSH}$ & \\
\hline Mikroegység & munkavállaló & háztartás és tagjai & \\
\hline Főbb változók & $\begin{array}{l}\text { bruttó keresetek, kor, } \\
\text { iskolai végzettség }\end{array}$ & $\begin{array}{l}\text { gazdasági aktivitás, } \\
\text { demográfiai jellemzők }\end{array}$ & \\
\hline Felhasználás & háztartások generálása & $\begin{array}{l}\text { munkanélkülivé válás } \\
\text { valószínűsége, időtartama }\end{array}$ & \\
\hline
\end{tabular}

Rövidítések: L11: Magyar Nemzeti Bank L11 kódú adatszolgáltatása, KHR: Központi Hitelinformációs Rendszer, SZJA: NAV szja-adatbázisa, Bértarifa: Nemzeti Munkaügyi Hivatal bértarifa-felmérése, MEF: Munkaerő-felmérés, NFSZ: Nemzeti Foglalkoztatási Szolgálat.

\section{Háztartások generálása}

Az ágensalapú modellek egyik előnye abban rejlik, hogy nagymértékủ heterogenitás szerepeltetésére képesek. A hitelezési kockázatoknál különösen fontos ez a heterogenitás: amennyiben több dimenzióban is eltérnek a szereplök, a nemteljesítés valószínűségét és a nemteljesítésből fellépő hitelezési veszteségek mértékét pontosabban és a valósághoz közelebb álló módon lehet számszerüsíteni. A nemteljesítés valószínủsége és a hitelezési veszteségek nagysága ugyanis nem az átlagos eladósodottságtól függ, hanem az eladósodottság eloszlásától, valamint a mögöttes háztartási jellemzőktöl. Így a makroprudenciális eszközök bankrendszerre gyakorolt hatásának számszerüsítéséhez elengedhetetlen a háztartások heterogenitásának szerepeltetése, a valósághoz minél közelebb álló eloszlásokat feltételezve.

Ágensalapú megközelítés esetén a hitelezési kockázatok és a lakáspiaci tranzakciók modellezése külön-külön is megkívánná a háztartások nagy számát: egy időszakban 
ugyanis a szereplőknek csak töredéke válik nemteljesítővé, vagy vásárol lakást a piacon, és így az egyes időszakok aggregált adataiban nagy volatilitást figyelhetnénk meg, ha kis mintát használnánk.

A fentiek miatt a modellben egymillió háztartást szerepeltettünk. A háztartások jellemzőit a fenti adatbázisokra támaszkodva határoztuk meg a következő lépésekben:

1. Az L11-adatbázist leszűkítettük a 2016-ban folyósított lakáscélú hitelekre.

2. Az így kapott megfigyelésekhez anonim azonosítók felhasználásával hozzákötöttük a KHR és a NAV 2016-os szja-adatbázisát. Így rendelkezésünkre álltak a hitelszerződések következő jellemzői: a hitelfelvevő háztartás bruttó jövedelme (adóstárs esetén adós és adóstárs jövedelme), a háztartásfö életkora, adóstárs jelenléte, vásárolt ingatlan értéke és a felvett hitel nagysága.

3. A háztartásfö életkora alapján minden megfigyeléshez hozzárendeltük, hogy az a modellbeli feltevések alapján első vagy második lakásvásárlásnak feleltethető-e meg: a 35 éves kor alattiak által felvett hitelek esetében beszélhetünk első, míg a 35 és 45 év közöttiek által felvett hitelek esetében második lakásvásárlásról. Utóbbi határ annak következménye, hogy a modell feltevése szerint a második lakásvásárlásra 10 évvel az első lakásvásárlás után kerül sor. Annak érdekében, hogy a modell feltevéseivel konzisztensek maradjunk, a 45 év feletti hitelfelvevők szerződéseit nem vettük figyelembe, amelyek a 2016-os lakáscélú hitelszerződések 17 százalékát tették ki.

4. Az életkor és bruttó jövedelem alapján az egyes megfigyelésekhez képzettséget rendeltünk (alapfokú, középfokú vagy felsőfokú végzettség) a 2016-os Bértarifa-adatbázis segítségével, amely anonim módon tartalmazza az adatbázisban szereplő személyek bruttó bérét és képzettségét. Képzettségi szintenként jövedelem és életkor alapján gyakorisági táblákat készítettünk. A gyakorisági táblák segítségével valószínűségeket rendeltünk a képzettségekhez, és az L11-adatbázisban szereplő háztartásokhoz a háztartásfö életkora és (adóstárs esetén egy keresőre jutó) bruttó jövedelme alapján a kapott valószínűségeknek megfelelően rendeltünk végzettséget.

5. A Bértarifa-adatbázis alapján megbecsültük a bér életkor szerinti növekedésének trendjét mindhárom képzettségi típusra. A bérnövekedés dinamikájának felhasználásával minden megfigyeléshez kezdő nettó bért rendeltünk (a továbbiakban béren nettó béreket értünk).

6. Minden megfigyeléshez előállítottuk a megfelelő lakásárarány-paramétert (kiinduló vagy középkori), amely a vásárolt lakás értékének az adott háztartás kezdőbéréhez viszonyított aránya, majd kiszámítottuk a másik lakásárarány-paramétert is. A középkori lakásárarány-paraméter másfélszerese a kiinduló lakásárarányparaméternek, összhangban azzal, hogy az L11-adatbázisban a 35-45 éves kor közötti lakásvásárlók átlagosan körülbelül 50 százalékkal magasabb áron vásároltak ingatlant, mint a 35 év alattiak.

7. A megfigyelésekből véletlenszerüen egymilliószor húzunk, és az így kapott sorok képezik a modellben szereplő egymillió háztartás háttéradatait.

8. Az L11-adatbázisban az első és második lakásvásárlónak tekintett megfigyelések esetében nem egyezik az adóstársak aránya. Célunk, hogy a modellbeli adóstársak 
aránya az L11-adatbázis második lakásvásárlóit jellemző aránnyal legyen összhangban. Ennek érdekében az L11-adatbázis második lakásvásárlónak tekintett háztartásainál képzettségi szintenként meghatároztuk az adóstárs létének a valószínűségét. Ezt követően a modellbeli háztartásokat egyfössé alakítottuk (egy före jutó értékkel számolunk tovább), majd a kapott valószínűségek alapján rendeltünk hozzájuk adóstársat (úgy, hogy az egy före jutó értékek ne változzanak).

9. Minden modellbeli háztartáshoz kezdővagyont rendeltünk oly módon, hogy a megtakarítási szabálya alapján a valós hitelszerződésben szereplő önerővel rendelkezzen a lakásvásárlás időpontjában, amely háztartásonként eltérő.

10. Minden modellbeli háztartás esetén a kiinduló hitelszerződés-adatok alapján rögzítettük, hogy milyen korban vásárolja meg az első és a második lakást (10 éves különbséget feltételezve), a tényleges életkorokat azonban újrageneráltuk egyenletes eloszlás alapján. Erre azért volt szükség, hogy a modell müködését ne zavarja meg a demográfiai jellemzők változása.

11. A modellben szereplő háztartások tehát a következő egyedi, az empíriából származó jellemzőkkel rendelkeznek (életkort leszámítva): kiinduló nettó jövedelem $\left(w_{i}^{0}\right)$, kezdővagyon $\left(B_{i}^{0}\right)$, lakásárarány-paraméter időfüggetlen értéke $\left(\theta_{i}^{0}\right)$, adóstárs $\left(n_{i}^{H}\right)$, lakásvásárlási életkor, képzettség.

A fentiek eredményeképpen a modellben szereplő egymillió háztartás a 2016-ban lakáshitelt felvevő háztartások jellemzőit tükrözi vissza, egyenletes koreloszlással.

\section{Kamatok és munkanélküliség}

A háztartások különböző kamatok mellett kapnak hitelt a banktól, ami a háztartás kockázatosságától függ. A háztartások egyedi kamatainak meghatározásához lineáris regressziós modellt becsültünk az L11- és az szja-adatbázis felhasználásával. A regressziós becslés eredményei a Függelék F1. táblázatában szerepelnek. ${ }^{8}$

$\mathrm{Az}$ ágensalapú modellben a háztartások által felvett hitel kamatának meghatározásakor a futamidőt és a kamatozás módját egységesen kezeltük: a futamidő 25 év, a felvett hitel pedig fix kamatozású, modellünkben jelenleg ugyanis nincs szerepe az alapkamat pályájának.

A munkanélküliségi adatok tekintetében a három képzettségi szint munkanélkülivé válásának valószínűségét a MEF-adatbázis 2017. III. negyedévi munkanélküliségi rátái alapján határoztuk meg $\left(\pi_{U, 1}=10,4\right.$ százalék, $\pi_{U, 2}=3,8$ százalék, $\pi_{U, 3}=1,5$ százalék). A munkanélküliként eltöltött idő hosszát szintén a MEF-adatbázis értékeit alapul véve határoztuk meg: alacsonyan képzettek esetén hat negyedév, közepesen képzettek esetén öt negyedév, magasan képzettek esetén négy negyedév. Ezek az időtartamok 1998 és 2015 között viszonylag stabilak maradtak, a válság időszakában sem mutattak érdemi kilengést.

\footnotetext{
${ }^{8}$ Aczél és szerzőtársai [2016] részletesen foglalkoznak a kamatok és felárak kérdésével, és a magyar lakáshitelekre vonatkozó regressziós eredményeik hasonlók.
} 


\section{A modell egyensúlyi illeszkedése}

A részletezett módszertan alapján egymillió háztartással futtattuk a modellt. A modell feltevései (súrlódásmentes és keresletvezérelt lakáspiac, egyenletes koreloszlás) következtében a modellben endogén módon nem alakulnak ki ciklusok, hanem a megfigyelt értékek idővel egyensúlyi állapot körül ingadoznak. Az ágensalapú modellek futtatására jellemző, hogy az első időszakok eredményeit figyelmen kívül hagyják (ez az úgynevezett burn-in szakasz). Ezt a szakaszt követően sokkok hiányában a modellünk el is érte az egyensúly körüli állapotot.

A modell futtatásához azon paramétereket, amelyeket nem közvetlenül az empíria alapján határoztunk meg, szakértői becsléseket figyelembe véve úgy állapítottuk meg, hogy a modell egyensúlyi viselkedése minél jobban leképezze a magyar lakáshitelezést. A lakáspiac szempontjából a legfontosabb információ a (hitel felhasználásával) vásárolt ingatlanok átlagos értéke, míg hitelezés szempontjából az átlagos kihelyezett hitelöszszeg. Érdemes ezen átlagos értékeket külön vizsgálni fiatal és középkorú hitelfelvevők szerint (a koreloszlás ugyanis a modell feltevése szerint egyenletes). Fontos kiemelni, hogy az egyensúlyi illeszkedés vizsgálatát a jelenlegi szabályozásnak megfelelően 50 százalékos PTI- és 80 százalékos LTV-korlát mellett végeztük.

A vásárolt lakások áraira és a felvett hitelösszegek értékére vonatkozó modellbeli és valós átlagos értékeket a 2. táblázat tartalmazza fiatal és középkorú bontásban. A táblázat alapján látható, hogy a modellbeli és a valós értékek alig különböznek egymástól.

\section{2. táblázat}

A felvett hitelösszegek és a lakások árának átlagos modellbeli és empirikus értékei (millió forint)

\begin{tabular}{lcccccc}
\hline & \multicolumn{3}{c}{ Fiatal } & & \multicolumn{2}{c}{ Középkorú } \\
\cline { 2 - 3 } \cline { 5 - 6 } & modell & valós & & modell & valós \\
\hline Hitelösszeg & 6,2 & 6,0 & & 8,0 & 7,8 \\
Lakásár & 11,1 & 11,1 & & 17,2 & 17,4 \\
\hline
\end{tabular}

A magyar bankrendszer hitelezési veszteségének nettó kamatjövedelemhez viszonyított aránya a válság előtti időszak átlagában (2005. I. negyedév és 2008. II. negyedév között) 12 százalék volt. A modell egyensúlyi helyzetében szinte ugyanekkora, 11 százalékos nettó kamatjövedelem-arányos hitelezési veszteséget produkált.

\section{Szimulációk}

A modell fejlesztésének hosszú távú célja, hogy támogassa a pénzügyi stabilitási kockázatelemzést és a makroprudenciális döntéshozatal folyamatát. A jelenlegi makroprudenciális eszköztár elemei közül az adósságfék- (PTI- és LTV-) szabályok hatnak a leginkább közvetlen módon a lakáshitelezés piacára. Pénzügyi stabilitási szempontból elsősorban a bankok jövedelmezőségét, illetve a bankrendszer stabilitását szükséges vizsgálni. A bankrendszert akkor tekintjük stabilnak, ha a tőkehelyzete 
negatív sokkok esetén is kellően erős marad ahhoz, hogy megfelelő mértékű hitelezési tevékenységet tudjon folytatni. Ennek megfelelően a modellben stabilitási szempontból azt vizsgáltuk, hogy a recesszió idején bekövetkező jövedelemcsökkenés hogyan viszonyul a normál időszakok jövedelmezőségéhez. A fenti szempontok mellett ugyanakkor a hitelezéssel fellépő társadalmi költségek miatt figyelembe kell venni a háztartásokat érintő jóléti hatásokat: intenzívebb hitelezés mellett a háztartások jobban tudják érvényesíteni a lakhatással kapcsolatos preferenciáikat, mindemellett ez magasabb kockázatokkal is jár (aminek a mértékét a háztartások gyakran nem tudják megfelelően felmérni), ami nemcsak a bankrendszerre ró költségeket, hanem a háztartásokra is. Ha túlzott eladósodottság esetén a háztartás nem tudja törleszteni a hitelét, és csődbe megy, elveszítheti ingatlanát és az ingatlan formájában felhalmozott vagyonának egy részét vagy egészét. A modellben a háztartások jólétét az átlagos lakásmérettel és a csődök számával vizsgáljuk. A csőd ténye és az ezzel járó bizonytalanság nagyobb hatással lehet a háztartások szubjektív jólétére, mint a tényleges pénzügyi veszteség. ${ }^{9}$

A jelenlegi szabályozás 50 százalékos PTI- és 80 százalékos LTV-korlátja mellett a bankrendszer negyedéves profitja a modellben 12,5 milliárd forint, ${ }^{10}$ a lakáshitelek 13 százaléka válik nemteljesítővé bármikor a 25 éves futamidő alatt, az átlagos lakásár pedig 13,1 millió forint.

\section{Sokkforgatókönyvek}

A PTI- és LTV-mutatók maximális értékére vonatkozó rögzített előírás másként hathat vissza a bankrendszerre különböző makrogazdasági forgatókönyvek esetén. ${ }^{11}$ Ennek megfelelően az alábbi forgatókönyvek szerint vizsgáltuk a feltételezett exogén sokkok bankrendszerre és háztartásokra gyakorolt hatását:

- 1-4. FORGATÓKÖNYv: gazdasági visszaesés következtében a bérek egyenletes ütemben csökkennek, majd a recesszióval megegyező hosszúságú alkalmazkodási időszakban fokozatosan érik el a kiinduló értéküket. Az egyes forgatókönyvek esetén a gazdasági visszaesés mértéke és időtartama eltérö, melyek konkrét nagyságát a 3. táblázat tartalmazza.

\footnotetext{
${ }^{9}$ A konkrét veszteségek erkölcsi kockázat esetében nem is összehasonlíthatók.

${ }^{10} \mathrm{~A}$ bankrendszer profitját úgy határoztuk meg, hogy a kamatjövedelemből kivontuk a hitelezési veszteségeket. A kamatjövedelmet a kamatbevétel $\rho$ hányadaként határoztuk meg, a magyar bankrendszer kamatjövedelmének és kamatbevételének átlagos arányából kiindulva. A feltüntetett bankrendszeri profit többek között azért nem összehasonlítható a bankok eredménykimutatásában szereplő profittal, mert a modell csak lakáscélú jelzáloghiteleket tartalmaz, a háztartások száma is kevesebb, és költségoldalon a hitelezési veszteségen túl nem jelennek meg egyéb banki költségek, mint például a mủködési költségek.

${ }^{11}$ Magyarországra a válság 2008 harmadik negyedévében gyűrüzött be, a tartós növekedés beindulására pedig 2013-ig kellett várni. Ezen időszak alatt átlagosan 3 százalékponttal volt magasabb a munkanélküliségi ráta, mint a válság kezdetekor. A reál-GDP a mélypontján több mint 9 százalékkal volt alacsonyabb a válság elötti csúcshoz képest. A válság által mélyen sújtott országok között azonban találhatunk olyanokat is, amelyek 20 százalék körüli GDP-visszaesést szenvedtek el (például balti államok). A szimulációk során emiatt 10 és 20 százalékpontos visszaesések hatását vizsgáltuk.
} 
- 5. FORGATÓKÖNYv: a gazdaságot elöször pozitív, majd negatív sokk éri: a kezdeti ötéves gazdasági felfutás alatt a bérek egyenletes ütemben összesen 20 százalékkal nőnek, majd egy negatív sokk hatására feleannyi idő alatt visszaáll a kiinduló bérszint. A felfutás idején a munkanélküliségi ráta 1 százalékpontot csökken, a recesszió alatt az eredeti értéknél 3 százalékponttal magasabb.

- 5.A FORGATóKÖNYv: a háztartások lakásárarány-paramétere független a lakásárak változásától $(\omega=0)$.

- 5.B FORGATÓKÖNYv: a lakások egységára rögzített, a felár 0 százalék (ennek következtében a háztartások sem változtatják a lakásárarány-paraméterüket a ciklus hatására, vagyis minden prociklikus csatornát lekapcsolunk).

- 5.C FORGATóкÖNYv: a bankrendszer is prociklikusan viselkedik: a gazdaság növekedése idején a PTI- és LTV-korlátok fokozatosan 10 százalékponttal lazulnak, a recesszió idején pedig fokozatosan visszaállnak az eredeti értékükre (a többi prociklikus csatorna megléte mellett).

\section{3. táblázat}

A gazdasági visszaesés jellemzői az 1-4. FORGATóKöNYVEK esetében

\begin{tabular}{lccccc}
\hline Forgatókönyv & \multicolumn{2}{c}{ A bérek csökkenése } & & \multicolumn{2}{c}{ A munkanélküliségi ráta növekedése } \\
\cline { 2 - 3 } \cline { 5 - 6 } & $\begin{array}{c}\text { mértéke } \\
\text { (százalék) }\end{array}$ & $\begin{array}{c}\text { időtartama } \\
(\text { év) }\end{array}$ & & $\begin{array}{c}\text { mértéke } \\
\text { (százalékpont) }\end{array}$ & $\begin{array}{c}\text { időtartama } \\
\text { (év) }\end{array}$ \\
\hline 1. & 20 & 2,5 & & 3 & 2,5 \\
2. & 20 & 5,0 & & 3 & 5,0 \\
3. & 10 & 2,5 & & 3 & 2,5 \\
4. & 10 & 5,0 & & 3 & 5,0 \\
\hline
\end{tabular}

Szemléltetésképpen az 1. ábrán láthatjuk, hogy az 1. FORGATóKÖNYV esetében hogyan alakul a lakáspiaci forgalom az ár és a volumen szempontjából. A jövedelem csökkenésével párhuzamosan a lakásvásárlásra fordított összeg is csökken. A kereslet csökkenésére a kínálati oldal a négyzetméterárak mérséklésével reagál, ezért a vásárolt összterület kisebb mértékben esik vissza. A recessziót követő alkalmazkodás során a bérek és így a lakásvásárlásra fordított összeg is nő, valamint a lakások négyzetméterára is emelkedik. Azt követően, hogy a bérek elérték kiinduló értéküket - mivel a lakáspiac felfutó szakaszban van -, a négyzetméterárak emelkednek. Tekintettel arra, hogy a lakásvásárlók érzékelik a lakáspiac felfutását, hajlandók valamivel többet fizetni a lakásokért, mint ami a normál idöszakra jellemző. A magasabb négyzetméterárak következtében azonban a vásárolt összterület már megegyezik a normál időszaki értékkel. A recesszió hatására tehát megfigyelhetünk egy ciklust a lakásárakban, de az alkalmazkodás következtében (mind a kínálati, mind a keresleti oldal viselkedése révén) endogén módon kialakul egy második, kisebb mértékü ciklus is.

A lakáspiaci ciklussal párhuzamosan hitelciklus is megfigyelhető a gazdaságban, amit a 2. ábra szemléltet. A recesszió kitörését követően mind a hitelkereslet, mind 
1. ábra

A lakásciklus alakulása az 1. FORGATóKÖNYV esetén

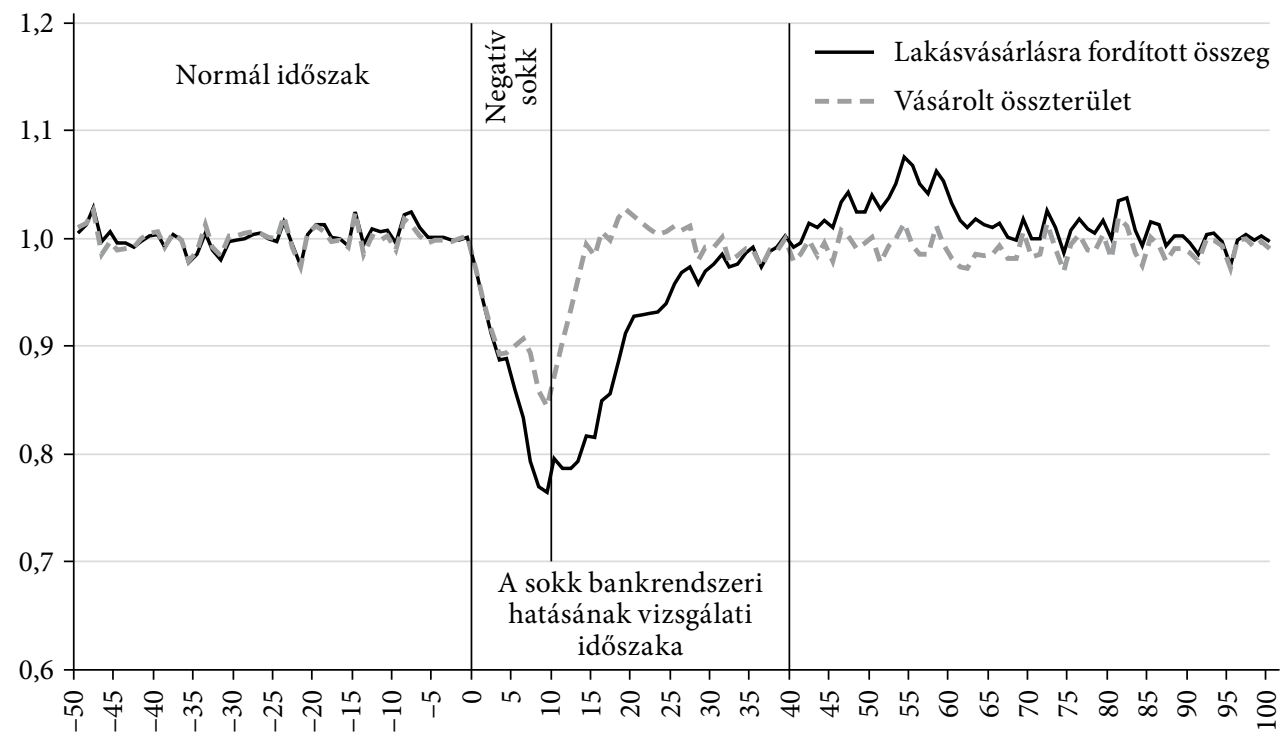

Megjegyzés: mindkét változó esetében a normál időszak átlagához viszonyított értékek szerepelnek. A vízszintes tengelyen a negyedévek száma látható. A 0 . negyedévben éri a negatív sokk a gazdaságot.

\section{2. ábra}

A hitelciklus alakulása az 1. FORGATóKÖNYV esetén

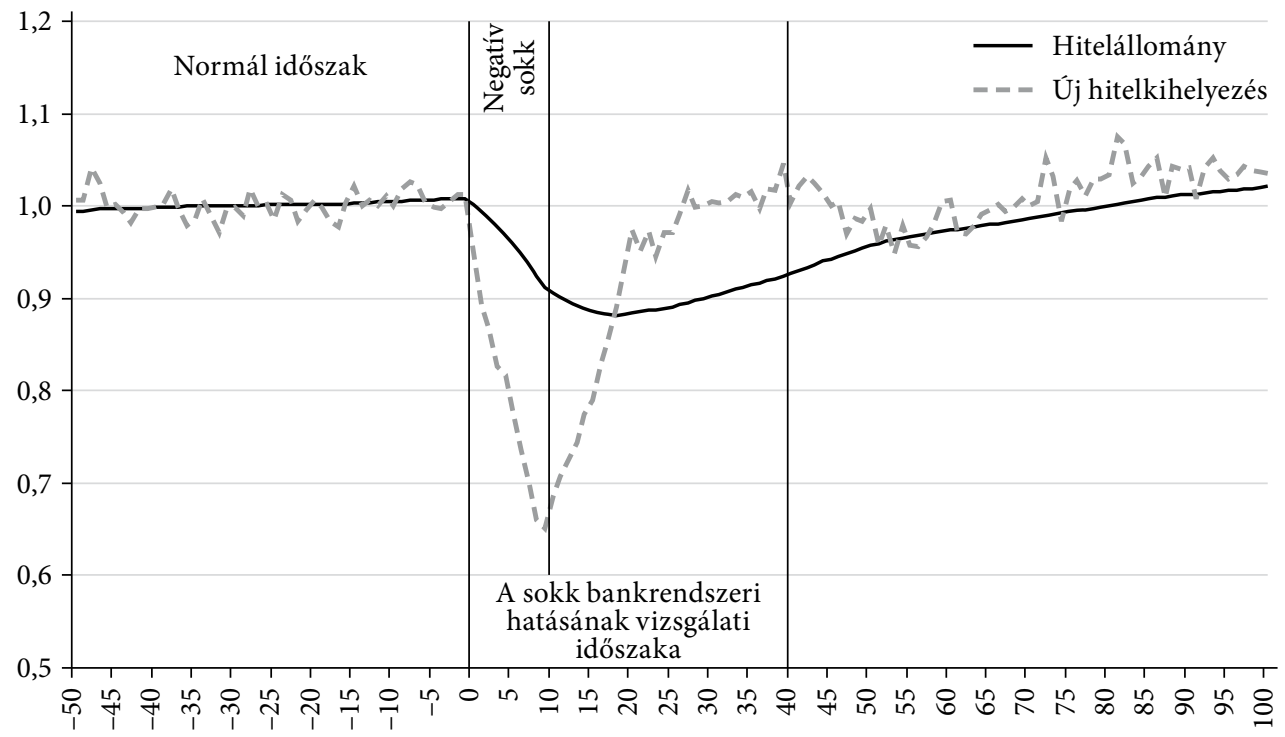

Megjegyzés: mindkét változó esetében a normál időszak átlagához viszonyított értékek szerepelnek. A vízszintes tengelyen a negyedévek száma látható. A 0 . negyedévben éri a negatív sokk a gazdaságot. 
3. ábra

A lakásciklus alakulása az 5. FORGATÓKÖNYv esetén

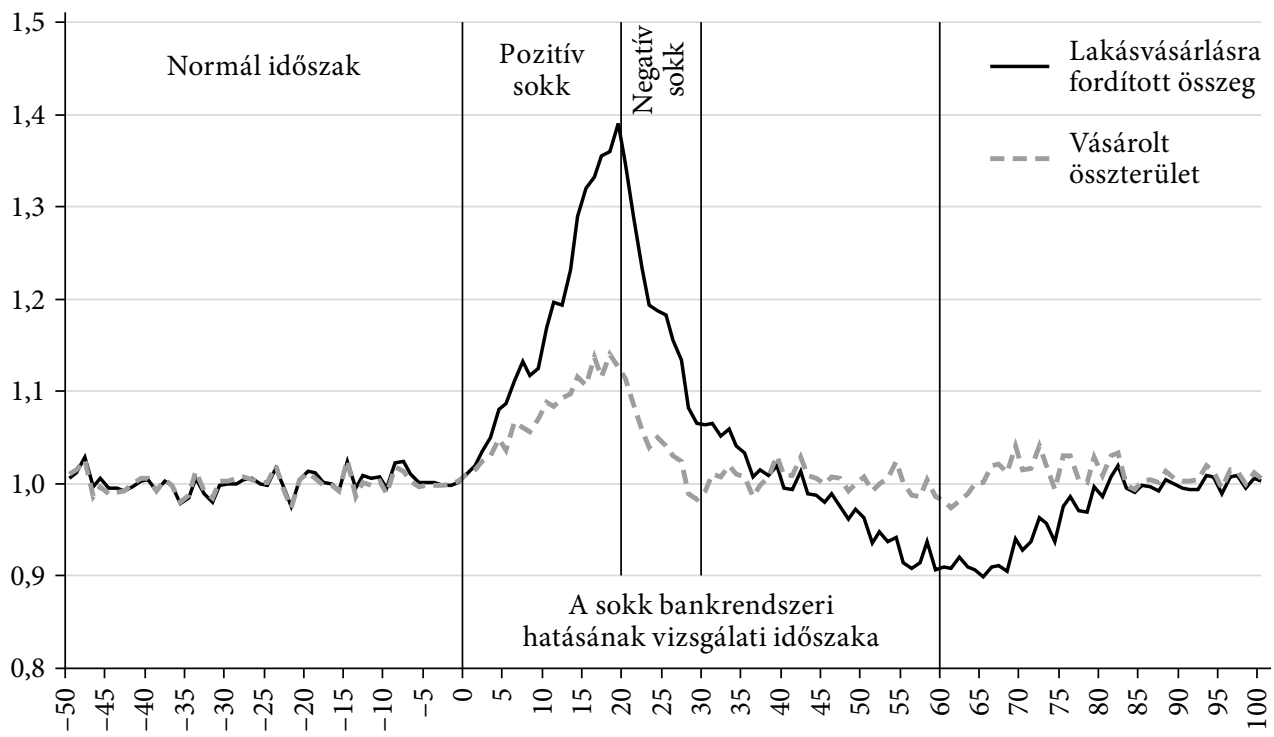

Megjegyzés: mindkét változó esetében a normál időszak átlagához viszonyított értékek szerepelnek. A vízszintes tengelyen a negyedévek száma látható. A 0. negyedévben éri a pozitív, míg a 20. negyedévben a negatív sokk a gazdaságot.

4. ábra

A hitelciklus alakulása az 5. FORGATóKÖNYV esetén

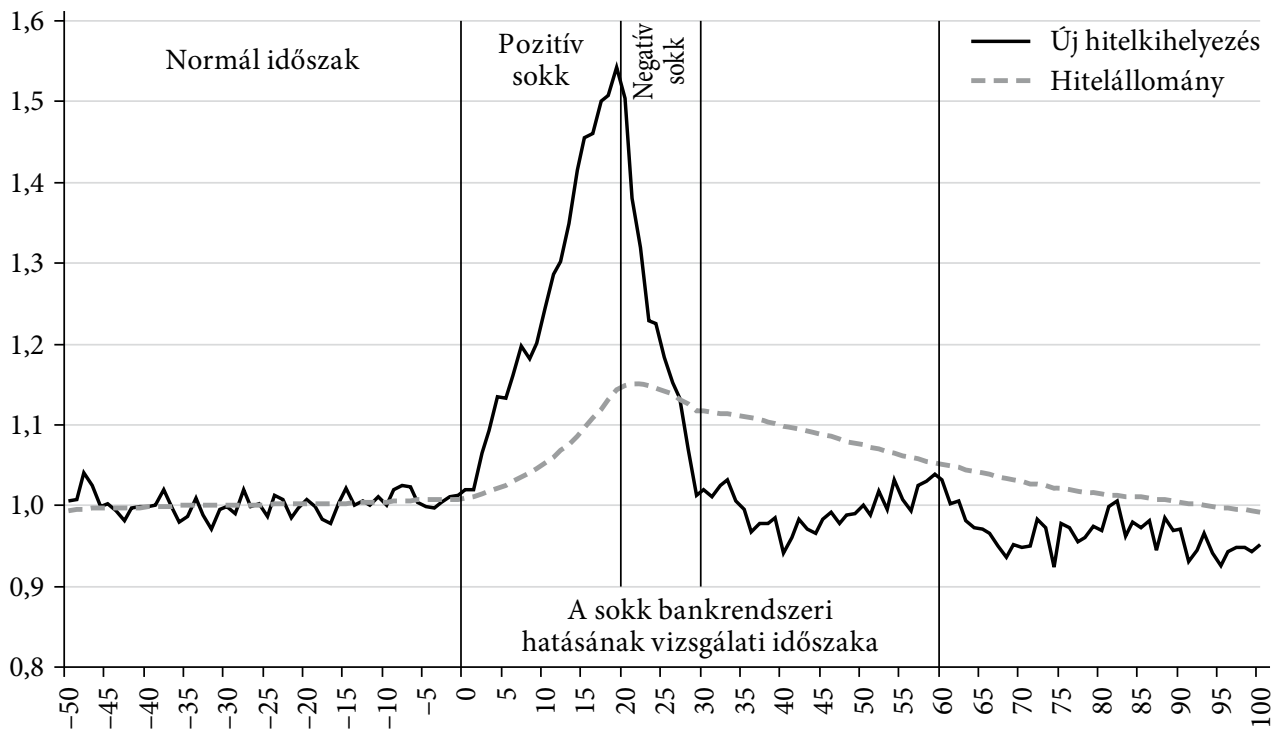

Megjegyzés: mindkét változó esetében a normál időszak átlagához viszonyított értékek szerepelnek. A vízszintes tengelyen a negyedévek száma látható. A 0. negyedévben éri a pozitív, míg a 20. negyedévben a negatív sokk a gazdaságot. 
a hitelkínálat mérséklődik: a háztartások az alacsonyabb jövedelmük miatt kisebb értékü ingatlanokat próbálnak megvásárolni, amihez átlagosan kevesebb hitelre van szükségük. Kínálati oldalról a háztartások hitelképessége szabhat korlátot: több olyan háztartás van, amelynek az alacsonyabb felhalmozott önerő, valamint az alacsonyabb jövedelem következtében az érvényben lévő PTI- és LTV-szabályok mellett a bankok csak kisebb hitelt nyújtanak. A gazdaság alkalmazkodásával párhuzamosan a hitelezés volumene is fokozatosan visszatér az átlagos szintjére. A hitelállomány alakulásában is láthatjuk a ciklust, ez azonban perzisztensebb a lakáspiaci ciklusnál, amit a hitelek hosszú futamideje magyaráz.

Az 1. FORGATÓKÖNYV egy exogén sokk hatására bekövetkező visszaesést, majd azt követő alkalmazkodást tartalmaz. Az 5. FORGATóкÖNYv dinamikája ennek fordítottja, a lakás- és a hitelciklus alakulása ennek megfelelően a fent részletezett mechanizmusok alapján alakul, de ellentétes irányban (3. ábra és 4. ábra).

Az 1-4. FORGATóKÖNYV esetén a sokk hatását 10 éves, az 5-5.C FORGATÓKÖNYV esetén 15 éves intervallumon vizsgáltuk (1-4. ábra), mivel utóbbi esetben ötéves fellendülés előzi meg a recessziót. Az egyes forgatókönyvek esetén kiszámítottuk a sokk idejére jellemző és a sokkot megelőző átlagos profit arányát, az átlagos csődök arányát és a lakásméret változását (4. táblázat).

\section{4. táblázat}

Különböző sokkforgatókönyvek összehasonlítása (PTI $=50$ százalék, LTV $=80$ százalék)

\begin{tabular}{lccc}
\hline Forgatókönyv & $\begin{array}{c}\text { Az átlagprofit } \\
\text { aránya }\end{array}$ & $\begin{array}{c}\text { Az átlagos csődszám } \\
\text { aránya }\end{array}$ & $\begin{array}{c}\text { Az átlagos lakásméret } \\
\text { aránya }\end{array}$ \\
\hline 1. & 0,7886 & 1,2329 & 0,9682 \\
2. & 0,6646 & 1,4765 & 0,9269 \\
3. & 0,8559 & 1,1958 & 0,9806 \\
4. & 0,6758 & 1,4026 & 0,9335 \\
5. & 0,9766 & 1,1442 & 1,0343 \\
$5 . A$ & 0,9789 & 1,0724 & 1,0239 \\
$5 . B$ & 0,9861 & 1,0811 & 1,0525 \\
$5 . C$ & 1,0035 & 1,1797 & 1,0374 \\
\hline
\end{tabular}

Megjegyzés: az egyes arányok a sokk időtartama alatti átlagos értékeknek a normál időszak alatti átlagos értékekhez viszonyított arányát jelentik. Az 5.C FORGATóKÖNYv esetében a PTI- és LTV-korlátok változnak, és a felfutás alatt érik el a maximális PTI $=50$ százalék és LTV $=80$ százalék értékeket.

Az 1-4. FORGATóKÖNYv esetében látható, hogy a negatív sokk hatására a bankrendszer jövedelmezősége csökken a csődök növekedésével párhuzamosan. Az átlagos lakásméret szintén csökken, mivel a háztartások jövedelme visszaesik, és így kevesebbet hajlandók lakásvásárlásra fordítani, valamint a háztartások a nagyobb munkanélküliség miatt kisebb önerőt tudnak felhalmozni, ami sok esetben hitelfelvételi korlátot is jelenthet. Látható, hogy a jobban elhúzódó 
visszaesések esetében (2. és 4. FORGATóKöNYv) a negatív hatás erőteljesebb, mivel a hosszabb időtartam alatt még több háztartást sújt munkanélküliség. Megállapítható továbbá, hogy a hosszabb időszakon át tartó magasabb munkanélküliségi ráta hatása erőteljesebb a jövedelemcsökkenés hatásánál: az 1. FORGATóKÖNYv 20 százalékos jövedelemcsökkenése esetében (ahol a recesszió két és fél éven át tart) mérsékeltebb a társadalmi kár, mint a 4. FORGATÓKÖNYV 10 százalékos jövedelemcsökkenésekor, ami viszont öt év alatt megy végbe.

Az 5-5.C FORGATÓKÖNYv esetében a negatív sokkot gazdasági fellendülés elözi meg, így még a negatív sokk idején is összességében magasabb a háztartások lakhatásra fordítható jövedelme (a GDP csökkenő szakaszában is magasabb az értéke, mint a normál időszakában). Emiatt a háztartások többet költenek lakhatásra, és nagyobb lakásokba költöznek. Az 5.B FORGATóKÖNYv esetén a legnagyobb a lakásméret növekedése, mert ebben az esetben a lakásárak nem emelkednek a kereslet növekedésével (lezártuk a modell prociklikus csatornáit), és így a nagyobb jövedelmekből arányosan nagyobb lakásokat tudnak vásárolni. Az 5-5.B FORGATóKÖNYv esetében a bankrendszer profitja összességében mégis csökken, mert a negatív szakaszban bekövetkezett csődökből eredő veszteség meghaladja a fellendüléskor elkönyvelt profitnövekményt. Ezzel szemben az 5.C FORGATóKöNYv esetében a bankok a fellendülés idején oldják a hitelezési feltételeket, ezért többet hiteleznek, és az ebből származó bevétel meghaladja a recesszió során keletkezett veszteséget. Fontos azonban azt is megjegyezni, hogy a bankrendszeri profit emelkedésével párhuzamosan a csődök száma ebben az esetben volt a legmagasabb, vagyis a hitelezési korlátok oldása miatt ebben az esetben a recesszió idején jóval több háztartás volt kénytelen értékesíteni az ingatlanát.

\section{Különböző LTV-és PTI-korlátok hatásának összehasonlitása}

Az eddigiekben a különböző sokkok hatását a jelenleg érvényben lévő PTI- és LTVkorlátok mellett vizsgáltuk. A következőkben elemzésünk keretét kibővítjük, és bemutatjuk, hogy különböző PTI-LTV kombinációk mellett hogyan alakul a bankrendszer jövedelmezősége (átlagos profitja), a háztartások esetében a csődök száma, valamint az átlagos lakásméret az 50 százalékos PTI- és a 80 százalékos LTV-korlátok eredményeihez viszonyítva.

Az 5. táblázat mutatja, hogy normál időben hogyan alakul a bankrendszer átlagos profitja. A PTI- és LTV-korlátok oldásával a hitelezés és így a kamatbevétel is növekszik. A táblázat értékei alapján láthatjuk, hogy ezzel párhuzamosan a bankrendszer profitja is nö. Ez nem szükségszerü, mert a hitelezés növekedésével a hitelezési veszteség is nőhet, mindenesetre az eredmények alapján a vizsgált nyugalmi időszakban a bevételnövelő hatás nagyobb. A korlátok oldódásával a háztartások is egyre nagyobb alapterületü lakásokat tudnak vásárolni (6. táblázat).

Normál időszakban mind a bankrendszer, mind a háztartás szempontjából kedvezőbbnek bizonyult a magasabb korlátok alkalmazása. Amikor azonban az alkalmazott PTI- és LTV-korlátok hatását szeretnénk összehasonlítani, nem elég 


\section{5. táblázat}

Átlagos profit az alapkombinációhoz képest különböző PTI-LTV kombinációk mellett

\begin{tabular}{lcccc}
\hline PTI (százalék) & \multicolumn{4}{c}{ LTV (százalék) } \\
\cline { 2 - 5 } & 60 & 70 & 80 & 90 \\
\hline 30 & 0,8559 & 0,9202 & 0,9608 & 1,0009 \\
40 & 0,8689 & 0,9361 & 0,9896 & 1,0261 \\
50 & 0,8753 & 0,9446 & 1 & 1,0398 \\
60 & 0,8787 & 0,9494 & 1,0062 & 1,0478 \\
\hline
\end{tabular}

Megjegyzés: a táblázat elemei azt mutatják meg, hogy az adott PTI-LTV kombináció melletti profit hogyan aránylik az alapestben $(\mathrm{PTI}=50$ százalék és LTV $=80$ százalék) realizált átlagos profithoz képest.

6. táblázat

A vásárolt lakások átlagos alapterületének eltérése az alapkombinációhoz képest (százalék)

\begin{tabular}{llllc}
\hline PTI (százalék) & \multicolumn{4}{c}{ LTV (százalék) } \\
\cline { 2 - 5 } & 60 & 70 & 80 & 90 \\
\hline 30 & $-6,8$ & $-4,3$ & $-2,0$ & $+0,2$ \\
40 & $-6,2$ & $-3,4$ & $-0,6$ & $+2,1$ \\
50 & $-5,9$ & $-2,9$ & alap & $+3,0$ \\
60 & $-5,7$ & $-2,6$ & $+0,3$ & $+3,5$ \\
\hline
\end{tabular}

\section{7. táblázat}

A normál időszaki profittól való eltérések kumulált összege a sokk bankrendszeri hatásának vizsgálati időszaka alatt (1. FORGATóKöNYv, milliárd forint)

\begin{tabular}{lcccc}
\hline PTI (százalék) & \multicolumn{4}{c}{ LTV (százalék) } \\
\cline { 2 - 5 } & 60 & 70 & 80 & 90 \\
\hline 30 & $-31,5$ & $-37,3$ & $-51,3$ & $-53,2$ \\
40 & $-41,3$ & $-62,7$ & $-78,5$ & $-97,4$ \\
50 & $-51,1$ & $-72,4$ & $-106,0$ & $-135,1$ \\
60 & $-57,3$ & $-90,4$ & $-113,7$ & $-152,6$ \\
\hline
\end{tabular}

Megjegyzés: a vizsgálati időszak a sokk kezdetétől számított 40 negyedév.

a normál időszakot alapul venni, hiszen éppen a különböző sokkok esetén materializálódhatnak olyan kockázatok, amelyek a megfelelően alkalmazott makroprudenciális eszközök segítségével csökkenthetők. A következőkben az 1. FORGATóKÖNYv alapján vizsgálódunk.

Minden kombináció esetében kiszámítottuk, hogy a sokkintervallumban a profit mennyivel tér el az egyes negyedévekben a normál időszaki értékéhez képest. 
A sokkintervallumra kumulált hatást a 7. táblázat tartalmazza. Látható, hogy a magasabb PTI- és LTV-korlátok a sokk bekövetkeztének hatására nagyobb kumulált veszteséget okoznak, mivel a bankok lazább hitelezési gyakorlata magasabb kockázatokhoz vezet, amelyek a sokk bekövetkeztével materializálódnak. A magasabb kumulált veszteség azonban nem feltétlenül jelenti azt, hogy az összprofit is alacsonyabb, hiszen ha normál időben jóval több jövedelemre tesznek szert a bankok, akkor nagyobb profitcsökkenés mellett is jövedelmezőbbek maradhatnak. A bankrendszer stabilitása szempontjából ugyanakkor fontos, hogy mekkora veszteséget kell elkönyvelnie a bankoknak: még ha összességében a normál időszak alatti nyereség felül is múlja a sokk hatására elszenvedett kumulált veszteséget, akkor sem egyértelmü, hogy kedvezőbbnek tekinthető egy olyan kombináció, amely válsághelyzetben jóval nagyobb tőkeszükséglettel jár, hiszen nem garantált, hogy a bankok a sokk bekövetkezésekor elegendő pufferrel vagy megfelelö tőkebevonási képességgel rendelkeznek ahhoz, hogy szolvensek maradjanak.

A lazább hitelezési standardok normál időben magasabb jövedelmezőséghez vezetnek, a vizsgált negatív sokk esetében viszont nagyobb veszteséggel párosulnak, így a bankrendszer szempontjából sem egyértelmü, hogy a hitelezési korlátok milyen kombinációja kívánatos. A bankrendszer szempontjából optimális kombináció kiválasztása nagyban függ attól, hogy milyen gyakran és milyen nagyságú negatív sokkok érik a gazdaságot. Emiatt megvizsgáltuk, hogy a sokk milyen gyakorisága mellett lennének a különböző PTI-LTV kombinációk kedvezőbbek az alapesethez képest. Ezen eredményeket a 8. táblázat tartalmazza. Az alapkombináció a bankrendszer szempontjából négy kombinációnál egyértelműen jobb, kilenc kombináció esetében nem dönthető el egyértelmủen, mert függ a sokk bekövetkezésének gyakoriságától, két kombinációnál pedig egyértelműen kedvezőtlenebbnek mondható. Ha az 1. FORGATóKÖNYV által meghatározott negatív sokkról feltételezzük, hogy várhatóan legalább 10 és legfeljebb 25 normál év után következik be, akkor csak egyetlen bizonytalan kombináció marad (lásd a 8. táblázat celláinak árnyalatait). Ilyen feltevések mellett a bankrendszer hosszú távú jövedelmezősége szempontjából nem célszerű a jelenlegi 80 százalékos LTV-korlátnál szigorúbb előírást alkalmazni.

Érdemes azonban a hitelfelvevő háztartások szemszögéből is összehasonlítani a különböző kombinációk hatását egy sokkot követően. A 9. táblázat azt tartalmazza, hogy az alapkombinációhoz képest hány százalékkal tér el a nemteljesítővé váló háztartások száma. Ha a normál időszak legalább 10 évig tart, a 90 százalékos LTV-korlát ugyan a bankrendszer jövedelmezősége szempontjából kedvezőbb lenne az alapesethez képest mindegyik vizsgált PTI-korlát mellett, a háztartások szempontjából azonban jóval kedvezőtlenebbnek bizonyulna, mivel jelentősen több háztartás válna nemteljesítővé.

Ha egy háztartásnak magasabb a jövedelemarányos törlesztőrészlete, akkor nagyobb valószínűséggel fog nemteljesítővé válni. Miközben az LTV-korlátok oldódnak, a háztartások a nagyobb hitel mellé nagyobb törlesztőrészletet vállalnak, és így arányaiban sokkal több háztartás esetében nő olyan szintre a jövedelemarányos törlesztőrészlet, hogy munkanélküliség esetén hamar nemteljesítővé válnak (5. ábra). Végső soron tehát mindkét korlát lazításával a magasabb jövedelemarányos 


\section{8. táblázat}

A különböző PTI-LTV kombinációk összevetése az alapkombinációval a bankrendszer jövedelmezősége szempontjából (1. FORGATóKöNYv)

\begin{tabular}{|c|c|c|c|c|}
\hline \multirow[t]{2}{*}{ PTI (százalék) } & \multicolumn{4}{|c|}{ LTV (százalék) } \\
\hline & 60 & 70 & 80 & 90 \\
\hline 30 & $s<0,3$ & $s<7,2$ & $s<26,1$ & $\begin{array}{c}\text { magasabb } \\
\text { jövedelmezőség }\end{array}$ \\
\hline 40 & $\begin{array}{c}\text { alacsonyabb } \\
\text { jövedelmezőség }\end{array}$ & $s<3,5$ & $s<42,9$ & $\begin{array}{c}\text { magasabb } \\
\text { jövedelmezőség }\end{array}$ \\
\hline 50 & $\begin{array}{c}\text { alacsonyabb } \\
\text { jövedelmezőség }\end{array}$ & $s<2,1$ & alap & $s>4,6$ \\
\hline 60 & $\begin{array}{c}\text { alacsonyabb } \\
\text { jövedelmezőség }\end{array}$ & $\begin{array}{c}\text { alacsonyabb } \\
\text { jövedelmezőség }\end{array}$ & $s>14,6$ & $s>9,5$ \\
\hline
\end{tabular}

Jelmagyarázat: a táblázatban a cellák árnyalatai azon feltételezés mellett mutatják, hogy mely kombináció esetén magasabb/alacsonyabb a bankrendszer átlagos jövedelmezősége a jelenlegi szabályozáshoz képest, hogy a normál időszak várható hossza 10 és 25 év közé esik $(10<s<25)$. Sötétszürke: alacsonyabb jövedelmezőség, világosszürke: magasabb jövedelmezőség, fehér: nem egyértelmü, közepesen szürke: jelenlegi szabályozás.

Megjegyzés: a táblázat elemei azt mutatják meg, hogy milyen esetben jövedelmezőbb az adott PTI-LTV kombináció az alapkombinációhoz képest. Az $s$ jelentése: normál időszak várható hossza években. Ha a profitabilitás alacsonyabb az alapesethez képest mind a normál időszakban, mind a sokkot követően vizsgált időszakban, akkor a bankrendszer jövedelmezősége szempontjából az adott kombináció egyértelműen kedvezőtlenebb. Ha a profitabilitás magasabb az alapesethez képest mind a normál időszakban, mind a sokkot követően vizsgált időszakban, akkor a bankrendszer jövedelmezősége szempontjából az adott kombináció egyértelmủen kedvezőbb. Egyéb esetben az egyes cellákban szereplő értékeket úgy számítjuk ki, hogy a sokk bankrendszeri hatásának vizsgálati időszaka alatti kumulált profitkülönbözetet (az alapkombináció kumulált profitja mínusz az adott kombináció kumulált profitja) elosztjuk a normál időszaki éves profitkülönbözettel (az adott kombináció normál profitja mínusz az alapkombináció normál profitja). Ha adott kombináció esetében normál időszakban magasabb a bankrendszer profitja az alapkombinációhoz képest (az 5. táblázat azonos cellájában lévő érték 1-nél nagyobb), a sokkot követően vizsgált időszakban pedig kisebb, akkor az adott kombináció abban az esetben kedvezőbb, ha a normál időszak várható hossza meghaladja ezt az értéket. Ha adott kombináció esetében normál időszakban alacsonyabb a bankrendszer profitja az alapkombinációhoz képest (az 5. táblázat azonos cellájában lévő érték 1-nél kisebb), a sokkot követően vizsgált időszakban pedig nagyobb, akkor az adott kombináció abban az esetben kedvezőbb, ha a normál időszak várható hossza kisebb ennél az értéknél. 


\section{9. táblázat}

Nemteljesítővé váló háztartások számának eltérése az alapkombinációhoz képest (1. FORGATóKÖNYv, százalék)

\begin{tabular}{lcccc}
\hline PTI (százalék) & \multicolumn{4}{c}{ LTV (százalék) } \\
\cline { 2 - 5 } & 60 & 70 & 80 & 90 \\
\hline 30 & $-35,5$ & $-17,9$ & $-8,2$ & $+6,9$ \\
40 & $-32,3$ & $-15,5$ & $-2,0$ & $+14,4$ \\
50 & $-30,6$ & $-12,7$ & alap & $+19,9$ \\
60 & $-30,1$ & $-12,0$ & $+2,2$ & $+21,9$ \\
\hline
\end{tabular}

törlesztőrészletek előfordulási gyakorisága miatt válik több háztartás nemteljesítővé. A 9. táblázat alapján az is látható, hogy a nemteljesítővé válás valószínüsége az LTVkorlátok oldásával nagymértékben nő, míg a PTI-korlát növelésének ennél jelentősen kisebb a hatása. Ez annak köszönhető, hogy a legtöbb háztartást az LTV-korlát köti, és nem a PTI, aminek következtében az LTV-korlátok oldódásával nagyobb arányban jelennek meg magas jövedelemarányos törlesztőrészletek, mint amikor rögzített LTV mellett csak a PTI-korlátot növeljük (6. ábra).

\section{5. ábra}

A háztartások tényleges jövedelemarányos törlesztőrészleteinek kvantilisei 50 százalékos PTI-korlát és különböző LTV-korlátok mellett

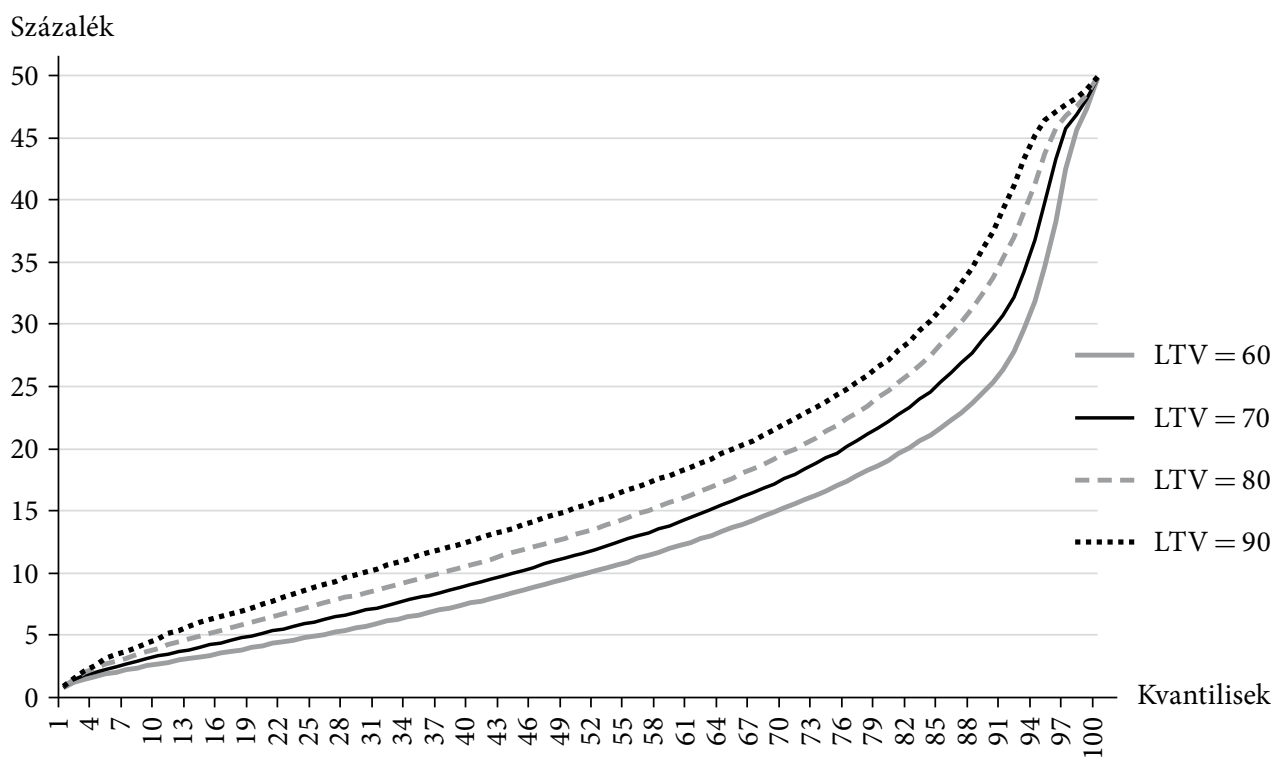

Az eredmények alapján a következő megállapításokat tehetjük: a makroprudenciális döntéshozónak több szempontot is mérlegelnie kell az optimális PTI-LTV kombináció meghatározásakor. A jelen modell szerint a bankrendszer jövedelmezősége 
6. ábra

A háztartások tényleges jövedelemarányos törlesztőrészleteinek kvantilisei 80 százalékos LTV-korlát és különböző PTI-korlátok mellett

\section{Százalék}

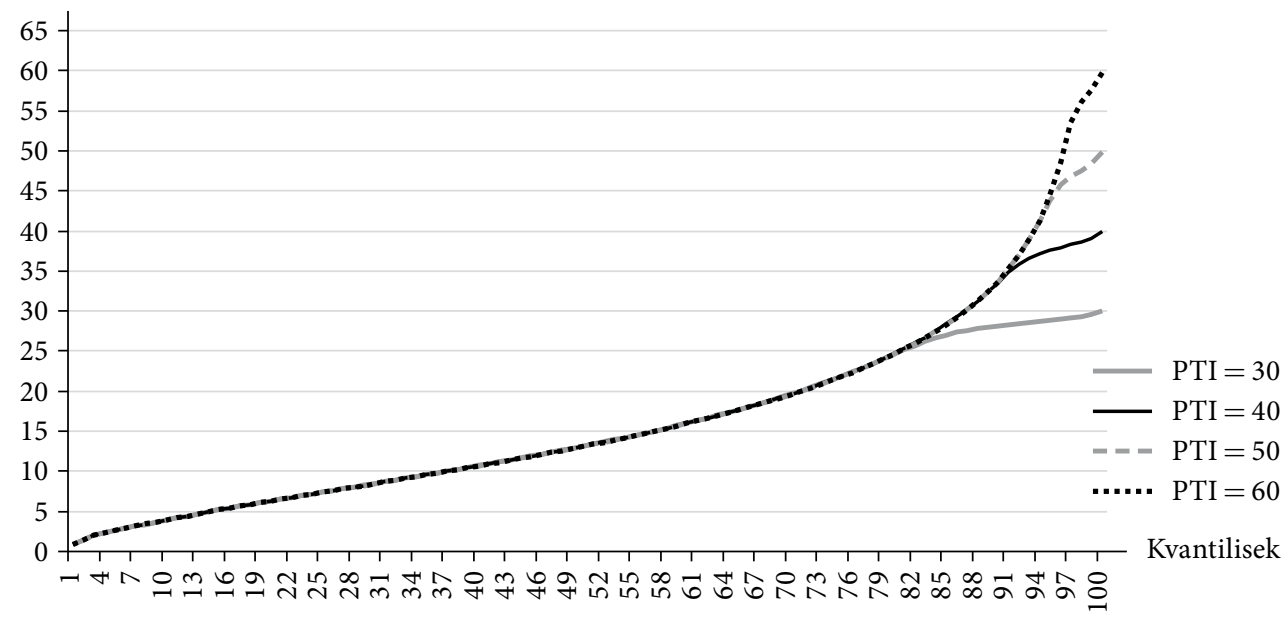

7. ábra

A bankrendszer jövedelmezősége és a háztartásokat érintő csődesemények közötti átváltás (1. FORGATÓKÖNYV)

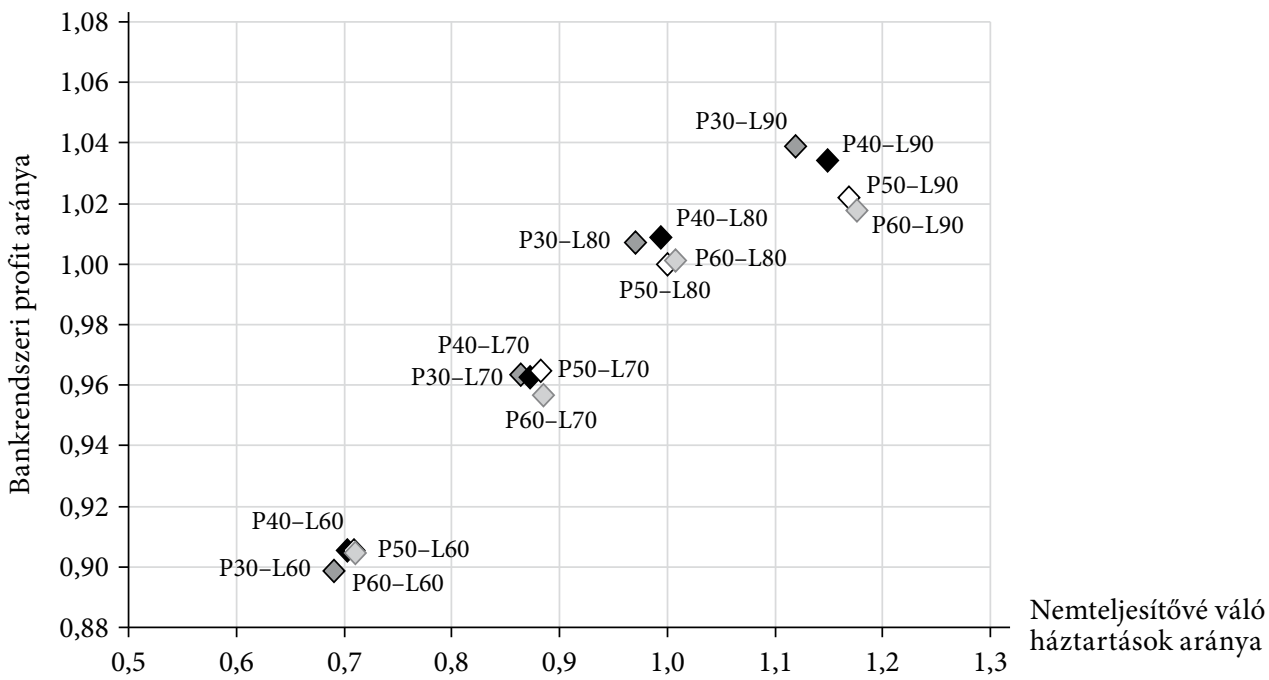

Jelmagyarázat: az egyes pontok felirataiban a P betű a PTI-re, az L betű az LTV-re vonatkozik. Például a P30-L60 felirat a 30 százalékos PTI és 60 százalékos LTV kombinációt jelöli.

Megjegyzés: az ábra pontjai azt mutatják meg, hogy az adott PTI-LTV kombináció melletti átlagos profit, illetve átlagos csődszám hogyan aránylik az alapesetben (PTI $=50$ százalék és LTV $=80$ százalék) realizált értékekhez. Az ábra értékeinek (a normál időszakot és a sokkot követő negyedéveket is magában foglaló átlagos profit, illetve átlagos csődszám) kiszámításához azzal a feltételezéssel éltünk, hogy a normál időszak hossza 20 év. Ha a normál időszak hosszát 10, 15 vagy 25 évre állítjuk, akkor is kvalitatíve ugyanezeket az eredményeket kapjuk. 
szempontjából a 80 százaléknál alacsonyabb LTV nem lenne kedvezőbb, míg a jelenlegi szabályozásnál magasabb LTV-korlát összességében jövedelmezőbb bankrendszert eredményezhet. Magasabb LTV-korlát mellett azonban jóval több háztartás válna nemteljesítővé (a 7. ábra a különböző szabályozások esetén a bankrendszer jövedelmezősége és a háztartásokat érintő csődesemények közötti átváltást szemlélteti), illetve a bankrendszer által a sokk hatására elszenvedett kumulált veszteség is jelentősen nagyobb lehet, ami a hirtelen jelentkező nagyobb tőkeszükséglet miatt jelenthet kihívást.

A makroprudenciális szabályozás országonként különböző, olykor az alkalmazott eszközök is eltérnek egymástól. ${ }^{12}$ Az eltérő szabályozást országspecifikus tényezők indokolhatják, például a háztartások törlesztési fegyelme és megtakarítási szokásai, a munkaerőpiac jellegzetességei, valamint az ingatlanpiacot, a jelzálogot és az adósokat érintő jogszabályi környezet. Ebből adódóan a magyar adatok felhasználásával kapott eredményekből nem lehet más országokra vonatkozóan következtetéseket levonni.

\section{Robusztusságvizsgálat}

A háztartások jellemzőit empirikus adatok alapján generáltuk. A modellben szereplő paramétereket pedig oly módon választottuk meg, hogy a modell egyensúlyi helyzetben minél jobban illeszkedjen a magyar lakás- és hitelpiac 2016. évi jellemzőihez. A ciklikus tényezőket nem kalibráltuk, mivel egyelöre csak egyetlen, a legutolsó magyar lakás- és hitelpiaci ciklusról áll rendelkezésünkre adat, ami nem elegendő stilizált tények megállapítására. A kapott eredményeinket azonban befolyásolhatja, hogy milyen sokk váltja ki a ciklust, valamint hogy a ciklus során milyen viselkedést feltételezünk. Emiatt érdemes megvizsgálni, hogy változnak-e az optimális PTI-LTV kombinációkkal kapcsolatos következtetések, ha más negatív sokkforgatókönyvet feltételezünk, illetve ha a ciklust befolyásoló paramétereket módosítjuk.

A 10-12. táblázat tartalmazza a visszaeséssel kezdődő 2-4. FORGATóкÖNYv esetén a 8. táblázattal megegyező tartalmú jövedelmezőségi vizsgálatot, amely a bankrendszer szempontjából értékeli a különböző PTI-LTV kombinációkat. Látható, hogy az eredmények robusztusak a gazdasági visszaesés mértékére és hosszára. A jelenleginél alacsonyabb LTV-korlát egyik alternatív negatív forgatókönyv mellett sem lenne kedvezőbb a bankrendszer jövedelmezősége szempontjából. A 8 . és a 11. táblázat, valamint a 10. és a 12. táblázat nagyon hasonló eredményre vezetnek, ugyanis az eredményeket jobban befolyásolja a visszaesés hossza (munkanélküliségnek való hosszabb kitettség), mint a jövedelemcsökkenés mértéke. Az eredmények alapján megállapítható, hogy rövidebb ideig tartó recessziók esetén akár egy magasabb PTI-korlát is kifizetődő lehet, míg egy hosszabban elnyúló recesszió

\footnotetext{
${ }^{12}$ Fáykiss és szerzőtársai [2018] részletesen bemutatja az Európai Gazdasági Térség országaiban alkalmazott adósságfékszabályokat.
} 
10. táblázat

Jövedelmezőségi vizsgálat (2. FORGATóKÖNYv: 20 százalékos visszaesés 5 év alatt)

\begin{tabular}{lcccc}
\hline PTI (százalék) & \multicolumn{4}{c}{ LTV (százalék) } \\
\cline { 2 - 5 } & 60 & 70 & 80 & 90 \\
\hline 30 & $s<6,6$ & $s<14,3$ & $s<45,7$ & $\begin{array}{c}\text { magasabb } \\
\text { jövedelmezöség } \\
40\end{array}$ \\
& $s<4,9$ & $s<11,2$ & $s<50,9$ & $\begin{array}{c}\text { magasabb } \\
\text { jövedelmezőség }\end{array}$ \\
50 & $s<3,6$ & $s<5,6$ & alap & $s>24,0$ \\
60 & $s<1,4$ & $\begin{array}{c}\text { alacsonyabb } \\
\text { jövedelmezöség }\end{array}$ & $s>91,4$ & $s>29,3$ \\
\hline
\end{tabular}

Megjegyzés: a táblázat elemei azt mutatják meg, hogy milyen esetben jövedelmezőbb az adott PTI-LTV kombináció az alapkombinációhoz képest. Az $s$ jelentése: a normál időszak várható hossza években. A táblázat értelmezésének részletes leírását a 8. táblázathoz tartozó megjegyzés és jelmagyarázat tartalmazza.

11. táblázat

Jövedelmezőségi vizsgálat (3. FORGATóKöNYv: 10 százalékos visszaesés 2,5 év alatt)

\begin{tabular}{|c|c|c|c|c|}
\hline \multirow[t]{2}{*}{ PTI (százalék) } & \multicolumn{4}{|c|}{ LTV (százalék) } \\
\hline & 60 & 70 & 80 & 90 \\
\hline 30 & $\begin{array}{c}\text { alacsonyabb } \\
\text { jövedelmezőség }\end{array}$ & $s<2,7$ & $s<20,7$ & $\begin{array}{c}\text { magasabb } \\
\text { jövedelmezőség }\end{array}$ \\
\hline 40 & $\begin{array}{c}\text { alacsonyabb } \\
\text { jövedelmezőség }\end{array}$ & $s<0,6$ & $s<27,4$ & $\begin{array}{c}\text { magasabb } \\
\text { jövedelmezőség }\end{array}$ \\
\hline 50 & $\begin{array}{c}\text { alacsonyabb } \\
\text { jövedelmezőség }\end{array}$ & $\begin{array}{c}\text { alacsonyabb } \\
\text { jövedelmezőség }\end{array}$ & alap & $s>5,5$ \\
\hline 60 & $\begin{array}{c}\text { alacsonyabb } \\
\text { jövedelmezőség }\end{array}$ & $\begin{array}{c}\text { alacsonyabb } \\
\text { jövedelmezőség }\end{array}$ & $s>30,2$ & $\mathrm{~s}>11,5$ \\
\hline
\end{tabular}

Megjegyzés: lásd a 10. táblázat alatti megjegyzést.

12. táblázat

Jövedelmezőségi vizsgálat (4. FORGATóKÖNYv: 10 százalékos visszaesés 5 év alatt)

\begin{tabular}{lcccc}
\hline PTI (százalék) & \multicolumn{4}{c}{ LTV (százalék) } \\
\cline { 2 - 5 } & 60 & 70 & 80 & 90 \\
\hline 30 & $s<6,3$ & $s<15,8$ & $s<47,9$ & $\begin{array}{c}\text { magasabb } \\
\text { jövedelmezóség } \\
40\end{array}$ \\
& $s<5,1$ & $s<11,2$ & $s<51,7$ & $\begin{array}{c}\text { magasabb } \\
\text { jövedelmezóség }\end{array}$ \\
50 & $s<3,2$ & $s<7,3$ & alap & $s>17,6$ \\
60 & $s<1,1$ & $s<1,6$ & $s>46,5$ & $s>25,7$ \\
\hline
\end{tabular}

Megjegyzés: lásd a 10. táblázat alatti megjegyzést. 
esetén egy a jelenleginél magasabb PTI-szabályozás kedvezőtlen lenne a bankrendszer stabilitása szempontjából. ${ }^{13}$

A ciklus lefutása a modellben leginkább a lakáspiaci felár változékonyságától $\left(\mu_{F}=0,4\right)$ függ, emiatt megvizsgáltuk, hogy változtat-e a PTI-LTV kombinációkra vonatkozó következtetéseken, ha kisebb $\left(\mu_{F}=0,3\right)$ vagy nagyobb $\left(\mu_{F}=0,5\right)$ paraméterértéket alkalmazunk. A 13. és 14. táblázat alapján a paraméter vizsgált módosításai érdemben nem változtatnak a modell következtetésein.

\section{3. táblázat}

Jövedelmezőségi vizsgálat $\mu_{F}=0,3$ paraméter mellett (1. FORGATóKÖNYv)

\begin{tabular}{|c|c|c|c|c|}
\hline \multirow[t]{2}{*}{ PTI (százalék) } & \multicolumn{4}{|c|}{ LTV (százalék) } \\
\hline & 60 & 70 & 80 & 90 \\
\hline 30 & $\begin{array}{c}\text { alacsonyabb } \\
\text { jövedelmezőség }\end{array}$ & $s<4,8$ & $s<22,6$ & $\begin{array}{c}\text { magasabb } \\
\text { jövedelmezőség }\end{array}$ \\
\hline 40 & $\begin{array}{c}\text { alacsonyabb } \\
\text { jövedelmezőség }\end{array}$ & $s<1,0$ & $s<32,9$ & $\begin{array}{c}\text { magasabb } \\
\text { jövedelmezőség }\end{array}$ \\
\hline 50 & $\begin{array}{c}\text { alacsonyabb } \\
\text { jövedelmezőség }\end{array}$ & $\begin{array}{c}\text { alacsonyabb } \\
\text { jövedelmezőség }\end{array}$ & alap & $s>7,4$ \\
\hline 60 & $\begin{array}{l}\text { alacsonyabb } \\
\text { jövedelmezőség }\end{array}$ & $\begin{array}{c}\text { alacsonyabb } \\
\text { jövedelmezőség }\end{array}$ & $s>55,1$ & $s>12,8$ \\
\hline
\end{tabular}

Megjegyzés: lásd a 10. táblázat alatti megjegyzést.

\section{4. táblázat}

Jövedelmezőségi vizsgálat $\mu_{F}=0,5$ paraméter mellett (1. FORGATóKÖNYv)

\begin{tabular}{|c|c|c|c|c|}
\hline \multirow[t]{2}{*}{ PTI (százalék) } & \multicolumn{4}{|c|}{ LTV (százalék) } \\
\hline & 60 & 70 & 80 & 90 \\
\hline 30 & $\begin{array}{c}\text { alacsonyabb } \\
\text { jövedelmezőség }\end{array}$ & $s<5,7$ & $s<24,4$ & $\begin{array}{c}\text { magasabb } \\
\text { jövedelmezőség }\end{array}$ \\
\hline 40 & $\begin{array}{c}\text { alacsonyabb } \\
\text { jövedelmezöség }\end{array}$ & $s<2,4$ & $s<27,6$ & $\begin{array}{c}\text { magasabb } \\
\text { jövedelmezöség }\end{array}$ \\
\hline 50 & $\begin{array}{c}\text { alacsonyabb } \\
\text { jövedelmezőség }\end{array}$ & $\begin{array}{l}\text { alacsonyabb } \\
\text { jövedelmezőség }\end{array}$ & alap & $s>5,3$ \\
\hline 60 & $\begin{array}{l}\text { alacsonyabb } \\
\text { jövedelmezöség }\end{array}$ & $\begin{array}{l}\text { alacsonyabb } \\
\text { jövedelmezőség }\end{array}$ & $s>40,2$ & $s>11,1$ \\
\hline
\end{tabular}

Megjegyzés: lásd a 10. táblázat alatti megjegyzést.

${ }^{13}$ Érdemes megjegyezni, hogy az alternatív forgatókönyvek esetén is azzal a feltevéssel éltünk, hogy a normál időszakok hossza 10 és 25 év közötti. Feltételezhető azonban, hogy egy olyan sokk, amely hosszabban elhúzódik, relatíve kisebb valószínűséggel következik be. Hasonlóan az is feltételezhető, hogy egy nagyobb mértékü visszaeséssel járó sokk is relatíve ritkábban fordul elő. Ezt figyelembe véve a makroprudenciális ajánlások szemszögéből még több esetben találnánk egyezést. 
A modellben eltérő megtakarítási szabály vonatkozik azon háztartásokra, amelyek lakást bérelnek, illetve amelyek saját tulajdonú ingatlanban laknak. A lakást bérlő háztartások megtakarítási szabályában lévő paramétereket úgy határoztuk meg, hogy a lakásvásárlás időpontjában a háztartás az empíriának megfelelő önerővel rendelkezzen a hitelfelvételhez. A lakástulajdonosok törlesztőrészletet is tartalmazó megtakarítási rátájára $(s=0,2)$ azonban érdemes érzékenységi vizsgálatot készíteni. A 15. táblázat 15 százalékos megtakarítási ráta, míg a 16. táblázat 25 százalékos megtakarítási ráta mellett tartalmazza a jövedelmezőségi vizsgálat eredményeit. Ezek alapján a 25 százalékos megtakarítási ráta hasonló következtetésekre vezet, mint a 20 százalékos. A 15 százalékos megtakarítási ráta mellett szintén igaz, hogy a 80 százalékos LTV-korlát csökkentése kedvezőtlenül érintené a bankrendszer jövedelmezőségét, emellett azonban megállapítható, hogy nincs egyetlen olyan PTI-LTV kombináció sem, amely egyértelműen kedvezőbb lenne a jelenlegi szabályozáshoz képest (a normál időszak hosszára tett feltevés mellett). Ez azonban nem meglepő, mivel a háztartások alacsonyabb megtakarítási hajlandósága szükségképpen nagyobb veszteségeket eredményez nemteljesítés esetén.

15. táblázat

Jövedelmezőségi vizsgálat $s=0,15$ paraméter mellett (1. FORGATóкÖNYv)

\begin{tabular}{lcccc}
\hline PTI (százalék) & \multicolumn{4}{c}{ LTV (százalék) } \\
\cline { 2 - 5 } & 60 & 70 & 80 & 90 \\
\hline 30 & $s<2,8$ & $s<10,8$ & $s<23,0$ & $s<23,2$ \\
40 & $s<2,6$ & $s<7,2$ & $s<18,3$ & $s>14,5$ \\
50 & $s<0,9$ & $s<2,1$ & alap & $s>44,0$ \\
60 & $s<0,4$ & $s<2,3$ & $s>62,3$ & $s>35,2$ \\
\hline
\end{tabular}

Megjegyzés: lásd a 10. táblázat alatti megjegyzést.

16. táblázat

Jövedelmezőségi vizsgálat $s=0,25$ paraméter mellett (1. FORGATóкÖNYv)

\begin{tabular}{|c|c|c|c|c|}
\hline \multirow[t]{2}{*}{ PTI (százalék) } & \multicolumn{4}{|c|}{ LTV (százalék) } \\
\hline & 60 & 70 & 80 & 90 \\
\hline 30 & $\begin{array}{l}\text { alacsonyabb } \\
\text { jövedelmezőség }\end{array}$ & $s<2,2$ & $s<30,7$ & $\begin{array}{c}\text { magasabb } \\
\text { jövedelmezőség }\end{array}$ \\
\hline 40 & $\begin{array}{c}\text { alacsonyabb } \\
\text { jövedelmezőség }\end{array}$ & $\begin{array}{c}\text { alacsonyabb } \\
\text { jövedelmezőség }\end{array}$ & $s<46,4$ & $\begin{array}{c}\text { magasabb } \\
\text { jövedelmezőség }\end{array}$ \\
\hline 50 & $\begin{array}{c}\text { alacsonyabb } \\
\text { jövedelmezőség }\end{array}$ & $\begin{array}{c}\text { alacsonyabb } \\
\text { jövedelmezőség }\end{array}$ & alap & $\begin{array}{c}\text { magasabb } \\
\text { jövedelmezőség }\end{array}$ \\
\hline 60 & $\begin{array}{c}\text { alacsonyabb } \\
\text { jövedelmezőség }\end{array}$ & $\begin{array}{c}\text { alacsonyabb } \\
\text { jövedelmezőség }\end{array}$ & $s>43,3$ & $s>2,8$ \\
\hline
\end{tabular}

Megjegyzés: lásd a 10. táblázat alatti megjegyzést. 


\section{Összegzés}

A tanulmányban egy keresletvezérelt ágensalapú lakáspiaci modellt mutattunk be, amelyben a heterogén háztartások lakásvásárlásukat részben hitelből finanszírozhatják. A modellszimulációban szereplő háztartások jellemzőit magyar adatbázisok felhasználásával határoztuk meg, elsősorban a 2016-ban folyósított lakáshiteleket tartalmazó mikroszintű adatbázisra (L11) támaszkodva. Minden hitelszerződésnek meg kell felelnie a makroprudenciális politika által meghatározott adósságfékszabályoknak, vagyis a PTIés az LTV-elöírásnak. A modellt különböző makrogazdasági sokkok mellett futtattuk, amelynek során a szimulációkban lakásár- és hitelciklus alakult ki.

A makroprudenciális politika célja olyan PTI-LTV szabályozás kialakítása, amely a bankrendszer stabilitása mellett nem ró túl nagy költséget a reálgazdaságra. Ennek megfelelően megvizsgáltuk, hogy a különböző PTI-LTV kombinációk hogyan hatnak a bankrendszer jövedelmezöségére, valamint a háztartások jólétére. Az eredmények alapján nem lehet egyértelmü iránymutatást megfogalmazni, az függ a sokkokra vonatkozó feltételezésektől, valamint a döntéshozó preferenciájától, mivel a bankok jövedelmezőségét és a háztartások jólétét eltérően befolyásolják a különböző előírások. A jelen modell szerint a bankrendszer jövedelmezősége szempontjából a 80 százaléknál alacsonyabb LTV nem lenne kedvezőbb, míg a jelenlegi szabályozásnál magasabb LTV-korlát összességében jövedelmezőbb bankrendszert eredményezhet. Magasabb LTV-korlát mellett - elsősorban az ebből fakadó magasabb jövedelemarányos törlesztőrészletek miatt - azonban jóval több háztartás válna nemteljesítővé. Emellett a bankrendszer által a sokk hatására elszenvedett kumulált veszteség is jelentősen nagyobb lehet, ami a hirtelen jelentkező nagyobb tőkeszükséglet miatt jelenthet kihívást.

A modell jelenlegi állapotában is képes megjeleníteni lakásár- és hitelciklusokat, az eredményekből leszűrhető kvalitatív következtetések pedig intuitívak. Annak érdekében, hogy a modell kvantitatív eredményeinek megbízhatóságát növeljük, a modellt számos ponton érdemes bővíteni. A modell keresletvezérelt jellegét az építőipar szerepeltetésével, valamint a lakáspiaci alkuk modellbe illesztésével oldhatjuk. Ha a négyzetméterárakat a lakások összterületétől tesszük függővé, a jövedelmek növekedése rövid távon még nagyobb ciklust generálhat a lakásárakban, ha pedig folyamatosan növekvő gazdaságot modellezünk, vizsgálhatjuk a jövedelmek emelkedésének hosszú távú hatásait is. A befektetési célú lakásvásárlók jelenléte felerősítheti a lakásárciklusokat, az ő szerepeltetésükhöz pedig szükséges a bérleti piac részletes modellezése. A bankrendszer szempontjából fontos elkülöníteni egymástól a fix és változó kamatozású lakáshiteleket, valamint érdemes bevezetni a lakások területi heterogenitását, mivel a fedezetérvényesítés lehetősége és költsége (és így a bankok potenciális vesztesége) az egyes alpiacokon eltérhet egymástól. A bankok heterogenitását például az eltérő hitelezési stratégiák megjelenítésével lehet bevezetni (az egyes bankok más-más korlátok mellett hajlandók hitelezni), és így megvizsgálható, hogy egy makrogazdasági sokk esetén a bankok sokkellenálló képességére hogyan hat, ha különböző kockázatvállalási hajlandóságot tanúsítanak. A hitelek átstrukturálásának lehetősége a hitelezési veszteségek pontosabb modellezését teheti lehetővé. 
Mivel a magyar PTI-szabályozás differenciált (elsősorban jövedelmi helyzet szerint), a későbbiekben szofisztikáltabb PTI-szabályokat is érdemes vizsgálni. Kamatemelési ciklus esetén a változó kamatozású hitelek kockázatosabbá válnak, így érdemes megvizsgálni a monetáris politika és a makroprudenciális politika kölcsönhatását is. Végezetül a lakáspiaci modell makrogazdasági modellbe való ágyazásával pontosabb képet kaphatunk a hitelezés, a lakáspiac és a reálgazdaság közötti visszacsatolási mechanizmusok hatásáról, ami lehetőséget nyújt a monetáris és a makroprudenciális politika interakciójának még pontosabb elemzésére.

\section{Hivatkozások}

Aczél Ákos-Banai ÁdÁm-Borsos András-Dancsik Bálint [2016]: A lakáshitelek felárát meghatározó tényezők azonosítása a magyar bankrendszerben. Hitelintézeti Szemle, 15. évf. 4. sz. 5-44. o.

Axtell, R.-Farmer, D.-Geanakoplos, J.-Howitt, P.-Carrella, E.-Conlee, B.Goldstein, J.-Hendrey, M.-Kalikman, P.-Masad, D.-Palmer, N.-YAng, C.-Y. [2014]: An Agent-Based Model of the Housing Market Bubble in Metropolitan Washington, D. C. Deutsche Bundesbank's Spring Conference on "Housing markets and the macroeconomy: Challenges for monetary policy and financial stability”. Kézirat, George Mason University, Oxford University, Yale University, Brown University.

Bak Dóra-Szabó Lajos Tamás [2016]: Munkaerőpiac. MNB Oktatási Füzetek, 6. sz.

Baptista, R.-Farmer, J. D.-Hinterschweiger, M.-Low, K.-Tang, D.-Uluc, A. [2016]: Macroprudential policy in an agent-based model of the UK housing market. Bank of England Staff Working Paper, 619. http://dx.doi.org/10.2139/ssrn.2850414.

Carstensen, C. L. [2015]: An agent-based model of the housing market. Steps toward a computational tool for policy analysis. University of Copenhagen, MSc-szakdolgozat.

Dancsik Bálint-Fábián Gergely-Fellner Zita-Horváth Gábor-Lang Péter-Nagy GÁbor-Olán Zsolt-Winkler SÁndor [2015]: A nemteljesítő lakossági jelzáloghitelportfólió átfogó elemzése mikroszintü adatok segítségével. MNB-tanulmányok, különszám, https://www.mnb.hu/letoltes/mnb-tanulmanyok-kulonszam-a-nemteljesitolakossagi-jelzaloghitel-portfolio-atfogo-elemzese.pdf.

Deissenberg, C.-Van Der Hoog, S.-Dawid, H. [2008]: EURACE: A massively parallel agent-based model of the European economy. Applied Mathematics and Computation, Vol. 204. No. 2. 541-552. o. https://doi.org/10.1016/j.amc.2008.05.116.

Erlingsson, E. J.-Teglio, A.-Cincotti, S.-Stefansson, H.-Sturluson, J. T.-Raberto, M. [2014]: Housing Market Bubbles and Business Cycles in an Agent-Based Credit Economy. Economics: The Open-Access, Open-Assessment E-Journal, 8. 1-42. o. http://dx.doi. org/10.5018/economics-ejournal.ja.2014-8.

Fáy kiss Péter-Palicz Alexandr-Szakács János-Zsigó Márton [2018]: Az adósságfékszabályok tapasztalatai a magyarországi lakossági hitelezésben. Hitelintézeti Szemle, 17. évf. 1. sz. 34-61. o. https://doi.org/10.25201/hsz.17.1.3461.

Ge, J. [2014]: Who Creates Housing Bubbles? An Agent-Based Study. Megjelent: Alam, S.Parunak, H. (szerk.): Multi-Agent-Based Simulation XIV. MABS 2013. Lecture Notes in Computer Science, Vol. 8235. Springer, Berlin-Heidelberg, 10. fejezet, https://doi. org/10.1007/978-3-642-54783-6_10. 
Gilbert, N.-Hawksworth, J. C.-Swinney, P. A. [2009]: An Agent-Based Model of the English Housing Market. Association for the Advancement of Artificial Intelligence, https:// pdfs.semanticscholar.org/b6f0/e4901b5469bb31418b368731c8636a616fd3.pdf.

Iacoviello, M. [2005]: House Prices, Borrowing Constraints, and Monetary Policy in the Business Cycle. American Economic Review, Vol. 95. No. 3. 739-764. o. https://doi. org/10.1257/0002828054201477.

Kannan, P.-RAbanal, P.-Scott, A. [2012]: Monetary and Macroprudential Policy Rules in a Model with House Price Booms. The B. E. Journal of Macroeconomics, De Gruyter, Vol. 12. No. 1. 1-44. o. https://doi.org/10.1515/1935-1690.2268.

KiYotaki, N.-Moore, J. [1997]: Credit Cycles. Journal of Political Economy, Vol. 105. No. 2. 211-248. o. https://doi.org/10.1086/262072.

Kiyotaki, N.-Michaelides, A.-Nikolov, K. [2011]: Winners and losers in housing markets. Journal of Money, Credit and Banking, Vol. 43. 255-296. o. https://doi.org/10.1111/j.15384616.2011.00374.x.

KuANG, P. [2014]: A model of housing and credit cycles with imperfect market knowledge. European Economic Review, Vol. 70. 419-437. o. https://doi.org/10.1016/j.euroecorev.2014.06.013.

Ortalo-Magné, F.-RAdy, S. [2006]: Housing market dynamics: On the contribution of income shocks and credit constraints. The Review of Economic Studies, Vol. 73. No. 2. 459-485. o. https://doi.org/10.1111/j.1467-937X.2006.383_1.x.

Ozel, B.-Nathanael, R. C.-Raberto, M.-Teglio, A.-Cincotti, S. [2016]: Macroeconomic implications of mortgage loans requirements: An agent based approach. Economics Department, Universitat Jaume I, Castellón, Working Papers, 2016/05.

Rubio, M.-Carrasco-Gallego, J. A. [2014]: Macroprudential and Monetary Policies: Implications for Financial Stability and Welfare. Journal of Banking and Finance, Vol. 49. 326-336. o. https://doi.org/10.1016/j.jbankfin.2014.02.012.

Rubio, M.-Comunale, M. [2016]: Lithuania in the Euro Area: Monetary Transmission and Macroprudential Policies. Bank of Lithuania, Working Papers, 2016/34.

\section{Függelék}

\section{Felhasznált adatbázisok}

A Magyar Nemzeti Bank L11 kódú adatszolgáltatása révén rendelkezésünkre áll egy mikroszintű adatbázis, amelyben a 2015. január 1-jét követően folyósított háztartásihitel-szerződések adatai találhatók. ${ }^{14}$ A változók között szerepelnek az adósra, a szerződés jellemzőire, kockázati paramétereire, valamint a mögöttes fedezetekre vonatkozó információk is. Az L11-adatbázis azon hitelekre vonatkozó megfigyeléseit használtuk fel, melyeket 2016-ban folyósítottak forintban lakáscélú felhasználásra jelzálogfedezet mellett (nem vettük figyelembe a hitelkiváltás céljából felvett hiteleket). A modell háztartásainak létrehozásához felhasznált adatok közül az L11-adatbázisból származnak a háztartásfő életkorára, az ingatlanfedezet értékére, valamint a felvett hitel összegére vonatkozó információk. A háztartások egyedi hitelkamatainak előállításához pedig felhasználtuk az L11-adatbázis követ-

\footnotetext{
${ }^{14}$ Az adatszolgáltatásban szereplő változók leírása megtalálható az MNB honlapján.
} 
kező változóit: ügyleti kamat, kamatozás módja, PTI, LTV, a felvett hitel összege, a háztartásfö életkora. Ezen felül az L11-adatbázis tartalmaz anonim ügyfél-, illetve szerződésazonosítót, amelyek révén összeköthető a Központi Hitelinformációs Rendszer adatbázisával, valamint a NAV szja-adatbázissal.

A Központi Hitelinformációs Rendszer (KHR) lakossági alrendszerében megtalálhatók a bankok és pénzügyi intézmények által - a törvényi elöírásnak megfelelően - havi rendszerességgel jelentett adatok minden magánszemélyeknek nyújtott hitel- és hiteljellegű szerződésről, valamint az adósról és adóstársakról. Az L11- és KHR-adatbázisok összekötése lehetővé teszi az adóstársak beazonosítását, ami elengedhetetlen ahhoz, hogy meghatározzuk a kétfős háztartások jövedelmét. Ezenkívül a KHR-ben szerepel a szerződés lejárata, így az egyedi kamat meghatározásához figyelembe lehet venni a futamidő nagyságát is.

A Nemzeti Adó- és Vámhivatal (NAV) által gondozott szja-adatbázis részletes bontásban tartalmazza az adóköteles személyek személyijövedelemadó-bevallásban szereplő jövedelemtételeit és adóterheit. Ezen információkat anonim módon hozzá lehet kapcsolni a mikroszintü L11-adatbázis megfigyeléseihez. A modell háztartásainak előállításához az adósok és adóstársak 2016-ra vonatkozó, munkaviszonyból származó bérjövedelmét, az összevont adóalapba tartozó jövedelmek összegét, valamint a jövedelemadó nagyságát használtuk fel.

A Bértarifa-felmérés munkavállalói adatokat anonim módon tartalmazó, mikroszintü adatbázis, amelyben szerepelnek a bruttó bérelemek, a munkavállaló néhány egyedi jellemzője, a munkaszerződés egyes elemei, továbbá számos vállalati jellemző. Ezek közül a bruttó keresetekre, valamint a munkavállaló iskolai végzettségére és korára vonatkozó 2016-os információkat használtuk fel a modell háztartásainak létrehozásához. A felmérést a Nemzeti Foglalkoztatási Szolgálat végzi éves gyakorisággal, aminek eredményeképpen jellemzően évi 100-200 ezer megfigyeléssel bővül az adatbázis. A mintavétel módjáról, valamint az adatbázisban szereplő változókról bővebb tájékoztatást nyújt például az MNB munkaerőpiaccal foglalkozó kiadványa (Bak-Szabó [2016]).

A Munkaerő-felmérés (MEF) célja a gazdasági aktivitás és a munkaerőpiaci folyamatok nyomon követése. A felmérés a Központi Statisztikai Hivatal (KSH) megbízásából készül havi rendszerességgel, többlépcsős, rétegzett mintavétellel. A mintába bekerülő háztartások hat egymást követő negyedéven keresztül szerepelnek a felmérésben, s negyedévente cserélódik a minta hatodrésze. Az adatbázis a megkérdezett háztartások tagjainak demográfiai jellemzőit, valamint a 15-74 éves személyek gazdasági aktivitására vonatkozó információkat tartalmazza. A felmérésben szereplő információk alapján állítottuk elő a háztartások munkanélkülivé válásának valószínűségét végzettségi szintenként, valamint a munkanélküliként eltöltött idő hosszát.

\section{A kamatregresszió eredményei}

A magyarázó változók szelekciója során figyelembe vettük, hogy az ágensalapú modellben mely változókat tudjuk szerepeltetni. A regressziós becslés során (a végső modellben) felhasznált magyarázó változók az alábbiak voltak: 
- A KAMATOZÁs MÓDJA (változó vagy fix ${ }^{15}$ ): a hosszabb távra rögzített kamatozású hitelek esetén magasabb a bank által viselt kamatkockázat, amelyet a bank fedezhet, ez azonban várhatóan emelkedö hozamkörnyezetben a forrásköltségét növeli,

- AZ ADÓsTÁRS JELENLÉTE: adóstárs bevonása (modellben kétfös háztartás) csökkenti a bank kockázatát,

- PTI: magasabb jövedelemarányos törlesztőrészlet a háztartás relatíve magasabb törlesztési terhe miatt növeli a nemteljesítés kockázatát,

- LTV: magasabb LTV mellett a hitel alacsonyabb fedezettsége miatt a bank potenciális vesztesége nagyobb,

- FUTAMIDő: egyfelől hosszabb futamidő alatt nagyobb valószínüséggel éri a háztartást olyan hatás, amely miatt nemteljesítővé válik, másfelől a lejárati eltérésből többletkockázata származik a banknak,

- SZERZŐDÉSES ÖSSZEG ÉS NÉGYZETE: a nagyobb szerződéses összeg mellett alacsonyabbak a bank egységnyi hitelre jutó költségei, de ez a hatás fokozatosan csökken,

- A HÁzTARTÁs JövEDELME: a magasabb jövedelemmel rendelkező háztartás kockázatossága kisebb, mivel a magasabb jövedelmüek kisebb valószínűséggel lesznek munkanélküliek, és nagyobb tartalékot tudnak felhalmozni,

- A HÁZTARTÁSI JÖVEDELEM ÉS ADÓsTÁRS INTERAKCIÓJA: a magasabb jövedelemmel járó kockázatcsökkenés mértéke adóstárs esetén kisebb,

- ÉLETKOR: feltételezésünk szerint az életkor növekedésével a hitelfelvevő kockázatossága csökken (a stabilabb munkapiaci helyzet miatt), ezzel összhangban áll a magyar bankok gyakorlata, mivel az L11-es megfigyeléseink alapján a 30 és 40 év közötti hitelfelvevők szignifikánsan alacsonyabb kamat mellett kaptak hitelt (ceteris paribus).

\footnotetext{
${ }^{15}$ Fix kamatozásúnak tekintettük azon hiteleket, amelyeknél a szerződésben rögzített kamatperiódus hossza meghaladja az öt évet.
} 
F1. táblázat

A lakáscélú jelzáloghitel kamatát meghatározó regressziós együtthatók

Magyarázó változó

Becsült együttható

Öt éven túl rögzített a kamatláb (indikátorváltozó)

$1,849^{* * *}$

$(0,0151)$

PTI (százalék)

$0,016^{* * *}$

$(0,0007)$

LTV (százalék)

$0,009^{\star * *}$

$(0,0005)$

Futamidő (hónap)

$0,002^{* * *}$

$(0,0001)$

Szerződéses összeg (forint, logaritmus)

$-3,511^{* * *}$

$(0,3210)$

Szerződéses összeg (forint, logaritmus) négyzete

$0,095^{\star * *}$

$(0,0104)$

Adóstárs kapcsolódik a hitelhez (indikátorváltozó)

$-0,825^{* * *}$

$(0,3070)$

Háztartás jövedelme (forint, logaritmus)

$-0,070^{\star * *}$

$(0,0197)$

Háztartás jövedelme (forint, logaritmus) × Adóstárs

$0,057^{* *}$

$(0,0239)$

Hitelfelvevő életkora (indikátorváltozó)

$-0,099^{* * *}$

$(0,0160)$

Konstans

$35,480^{* * *}$

$(2,5230)$

$N$

22527

$R^{2}$

0,421

Megjegyzés: zárójelben a standard hiba látható.

${ }^{* * *} p<0,01,{ }^{* *} p<0,05,{ }^{*} p<0,1$. 
F2. táblázat

Paraméterek

A paraméter neve

A háztartások száma

Jelölés

Érték

Felnőttkor hossza negyedévekben

1000000

A nyugdíjaskor kezdő negyedéve

A bérleti díj háztartási jövedelemhez viszonyított aránya

A nyugdíj aránya az utolsó munkajövedelemhez képest

$\begin{array}{cc}N_{H} & 1000000 \\ n_{L} & 240 \\ n_{P} & 180 \\ \beta & 0,3 \\ r^{P} & 0,8 \\ \rho & 0,45 \\ s^{R} & 0,2 \\ s_{0}^{R} & 0,05 \\ \xi & 0,01 \\ \varsigma_{1} & 1,5 \\ \varsigma_{2} & 0,8 \\ n_{Y} & 40 \\ \delta & 0,4 \\ l_{P} & 100 \\ \Upsilon & 0,45\end{array}$

A fedezetérvényesítésből befolyt összeg aránya az ingatlan piaci értékéhez

A kamatjövedelem aránya a kamatbevételekhez

A lakástulajdonosok megtakarítási rátája

A lakásbérlők minimális megtakarítási rátája

A lakásbérlők megtakarítási határrátája

A középkori és kiinduló lakásárarány-paraméterek egymáshoz viszonyított aránya

A nyugdíjaskori és középkori lakásárarány-paraméterek egymáshoz viszonyított aránya

A fiatalkorban vásárolt lakásban eltöltött negyedévek száma

A minimális fogyasztási kiadások normáljövedelemhez viszonyított aránya

Lakáshitelek futamideje negyedévekben

Erkölcsi kockázat miatti bedőlés esetén a bank veszteségének mértéke a fennálló tartozáshoz viszonyítva

A lakáspiaci felár meghatározásakor a figyelembe vett korábbi időszakok száma

A lakáspiaci felár aránya a lakások összterületének átlagtól való százalékos eltéréséhez képest

A lakáspiaci felár csökkenésének mértéke átlag alatti összterület esetén

Lakásárarány-paraméterek érzékenysége a lakáspiaci felárakra

$\kappa \quad 0,8$

Erkölcsi kockázathoz szükséges minimális jövedelemarányos törlesztőrészlet

$\begin{array}{cc}n_{F} & 50 \\ \mu_{F} & 0,4 \\ \phi & 0,9 \\ \omega & 0,7 \\ P T I^{m} & 0,3\end{array}$

Az erkölcsi kockázat skálázási együtthatója

$\eta \quad 0,2$ 
F3. táblázat

A modell változóinak jelölése

A változó neve

Jelölés

HÁzTARTÁsoK

Kezdővagyon

$B_{i}^{0}$

Vagyon

$B_{i, t}$

Jövedelem

$y_{i, t}$

Fogyasztás

$c_{i, t}$

Lakástulajdon: saját tulajdonú lakás esetén értéke 1 , különben 0

$F_{i, t}$

A lakás bérleti díja

$r_{i, t}^{F}$

A fennálló lakáshitel nagysága (tőketartozás)

$L_{i, t}$

A lakáshitel törlesztőrészlete

$l_{i, t}$

Életkor

$a_{i, t}$

Lakásvásárláshoz, -eladáshoz kapcsolódó pénzmozgás

$c_{i, t}^{F}$

Munkajövedelem

$w_{i, t}$

Nyugdíj

Potenciális bér

$y_{i, t}^{P}$

$w_{i, t}^{P}$

A lakásbérlők megtakarítási rátája

A tagok száma (1 vagy 2)

Kezdőbér

$s_{i, t}$

$n_{i}^{H}$

$w_{i}^{0}$

Az első lakásvásárlás rezervációs árának kezdőbérhez viszonyított aránya

$\theta_{i, t}$

A lakásárarány-paraméter időfüggetlen értéke

Az erkölcsi kockázatból fakadó nemteljesítés valószínűsége

Jövedelemarányos törlesztőrészlet $P T I_{i, t}$

Fedezetarányos hitelállomány $L T V_{i, t}$

A lakáshitel kamata

A bank vesztesége a nemteljesítő lakáshitelen

A saját tulajdonú lakás piaci értéke 